Anuario da Facultade de Dereito da Universidade da Coruña

Vol. 20 (2016), pp. 161-187

ISSNe: 2530-6324 || ISSN: 1138-039X

DOI: https://doi.org/10.17979/afdudc.2016.20.0.1920

\title{
REGULACIÓN ACTUAL DE LA MEDIDA DE SEGURIDAD DE LIBERTAD VIGILADA Y SU APLICACIÓN POR PARTE DE LOS TRIBUNALES
}

\author{
MARC SALAT PAISAL \\ Profesor de Derecho Penal \\ Universidad de Lleida
}

Fecha de recepción: 30.6.2016

Fecha de aceptación: 15.7.2016

\begin{abstract}
Resumen: En el presente trabajo se pretende realizar un análisis jurídico de la medida de seguridad de libertad vigilada prevista en el derecho penal español. Desde su aprobación a través de la LO 5/2010 han transcurrido ya más de cinco años y su regulación ha sufrido ya una modificación. Este lapso de tiempo permite recoger las manifestaciones que la doctrina ha vertido sobre la regulación positiva de la medida así como aportar propuestas sobre algunos de los principales escollos que presenta la misma. Al mismo tiempo, es posible contrastar como los tribunales españoles están aplicando la libertad vigilada lo que, a su vez, permite poner de relieve los principales problemas interpretativos que parece que se están encontrando los operadores jurídicos a la hora de aplicar la regulación de la libertad vigilada.
\end{abstract}

Palabras clave: medidas de seguridad; libertad vigilada; delincuentes imputables peligrosos; aplicación por parte de las audiencias provinciales.

Abstract: In the present work I try to carry out a legal analysis of the security measure of supervised release under the Spanish criminal law. Since its approval by the LO $5 / 2010$ it have passed more than five years and its regulation has undergone one change. This time period permits us to pick up the opinions of the specialist doctrine about the measure and make proposals on some of the major pitfalls of it. At the same time, it is possible to contrast how the Spanish courts are applying the supervised realease which, in turn, allows us to highlight the major interpretive issues that legal operators are finding when they have to apply it. 
Keywords: security measures; supervised release; dangerous offenders; measure's implementation by criminal courts.

\begin{abstract}
SUMARIO: I. INTRODUCCIÓN. II. EL PORQUÉ DE LA REGULACIÓN DE LA MEDIDA DE SEGURIDAD DE LIBERTAD VIGILADA. III. CONCEPTO Y CONTENIDO DE LA LIBERTAD VIGILADA. IV. PRESUPUESTOS PARA SU IMPOSICIÓN EN SENTENCIA. V. LA DETERMINACIÓN JUDICIAL DEL CONTENIDO DE LA MEDIDA Y SU RÉGIMEN DE EJECUCIÓN. VI. EL INCUMPLIMIENTO DE LA LIBERTAD VIGILADA. VII. CONCLUSIONES.
\end{abstract}

\title{
I. INTRODUCCIÓN
}

Una de las novedades más relevantes de la reforma operada en el Código Penal a través de la LO 5/2010 fue la inclusión de una nueva medida de seguridad no privativa de libertad: la libertad vigilada. Las razones de su relevancia no residían tanto en el contenido concreto de la nueva medida cuanto en la decisión de prever, por primera vez desde el Código Penal de 1995, la imposición de una medida de seguridad para sujetos plenamente imputables, pues hasta ese momento el CP español había establecido un sistema de sanciones más próximo a uno monista o al llamado nuevo monismo ${ }^{1}$. Justamente, frente a sujetos imputables, la medida de seguridad de libertad vigilada debe imponerse -tal como sucede respecto de los inimputables- en sentencia, pero su ejecución se pospone hasta el definitivo licenciamiento de la pena de prisión que obligatoriamente debe acompañarla ${ }^{2}$.

En el presente artículo se realiza un análisis jurídico del instituto de la medida de seguridad de libertad vigilada aplicable a sujetos imputables en el que se pretende dar

\footnotetext{
${ }^{1}$ Abordar el análisis del fundamento y medidas de seguridad y de los distintos sistemas de sanciones penales existentes supera en creces el objetivo de este trabajo. Sobre ello vid., entre otros, los trabajos de SANZ MORÁN, A. J., Las medidas de corrección y de seguridad en el derecho penal, Ed. Lex Nova, 2003; LEAL MEDINA, J., Un estudio de las actuales medidas de seguridad y los interrogantes que plantean en la moderna dogmática del Derecho penal, Ed. Aranzadi, 2008; SILVA SÁNCHEZ, J. Ma , El nuevo Código Penal: cinco cuestiones fundamentales, Ed. Bosch, 1997; CEREZO MIR, J., "Reflexiones críticas sobre algunas manifestaciones de la moderna tendencia a incrementar el rigor en la exigencia de responsabilidad criminal", en Revista penal, núm. 22, 2008; MUÑOZ CONDE, F., "Monismo y dualismo en el Derecho penal español", Estudios penales y criminológicos, núm. 6, 1981-1982; MAZA MARTÍN, J. M., "La necesaria reforma del Código Penal en materia de medidas de seguridad", en ECHAVARRI GARCÍA, M., Las penas y medidas de seguridad, Ed. Consejo General del Poder Judicial. Centro de Documentación Judicial, 2007; SALAT PAISAL, M., La respuesta jurídico-penal a los delincuentes imputables peligrosos: especial referencia a la libertad vigilada, Ed. Aranzadi, 2015.

${ }^{2}$ Sobre esta cuestión son interesantes los trabajos sobre la problemática de los delincuentes imputables peligrosos y las distintas alternativas para su tratamiento. Sobre ello, vid. SALAT PAISAL, M., La respuesta jurídico-penal a los delincuentes imputables peligrosos: especial referencia a la libertad vigilada, Ed. Aranzadi, 2015, SANZ MORÁN, A. J., "La nueva medida de libertad vigilada: reflexión político-criminal", en MUÑOZ CONDE, F., et al. (Dirs.), Un Derecho penal comprometido. Libro homenaje al Prof. Dr. Gerardo Landrove Díaz, Ed. Tirant lo Blanch, Valencia, 2011; GARCíA ALBERO, R., «De las medidas de seguridad», en QUINTERO OLIVARES, G. (Dir.), Comentarios al Código Penal español, Ed. Aranzadi, 2016; ROBLES PLANAS, R., "Sexual Predators. Estrategias y límites del derecho penal de la peligrodidad", Indret, 4/2007.
} 
cuenta de su regulación positiva y de las modificaciones sufridas por la reforma del Código Penal operada por la LO 1/2015. Asimismo, se efectúa un análisis jurisprudencial en el que se pretenden poner de relieve las principales cuestiones conflictivas que se han planteado en los tribunales españoles en la imposición de la medida de libertad vigilada.

\section{EL PORQUÉ DE LA REGULACIÓN DE LA MEDIDA DE SEGURIDAD DE LIBERTAD VIGILADA}

Según la Exposición de Motivos de la LO 5/2010, la libertad vigilada se incorpora al ordenamiento jurídico-penal español para hacer frente a la peligrosidad subsistente de aquellos sujetos frente a quienes la pena no logra cumplir con su fin preventivo-especial, de modo que, según el legislador, la libertad vigilada se convierte en la alternativa a una prolongación ilimitada de la privación de la libertad. No obstante, la concreta regulación de la libertad vigilada es mucho más turbia en lo que a su aplicación a estos sujetos se refiere, de modo que no es posible vislumbrar con tanta facilidad su naturaleza de medida de seguridad. Ésta, en tanto que medida de seguridad, debe estar orientada a la consecución de fines de prevención especial y en concreto a la resocialización del sujeto sometido a la misma. En cambio, lo que en verdad se persigue con su introducción no es más que lo que la propia Exposición de Motivos dice no pretender: la inocuización de los sujetos considerados peligrosos a través de la imposición de una medida de seguridad. Tal aserción se deduce de la propia Exposición de Motivos, en tanto que -a diferencia de la del Proyecto de reforma del Código Penal de 2009- se indica que con esta nueva medida de seguridad lo que se pretende es tutelar la seguridad y la libertad del resto de ciudadanos ${ }^{3}$. Esta finalidad inocuizadora queda además confirmada, como posteriormente se verá, al analizarse el propio contenido de la medida, que fundamentalmente está orientado al control del propio sujeto y a la protección de las víctimas de los delitos previamente cometidos; no en cambio al tratamiento de las personas peligrosas como sí se establecía en la Exposición de Motivos del Proyecto de $2009^{4}$. Si, como se dice, su inclusión en el Código Penal pretende hacer frente a la falta de efecto rehabilitador que tiene la pena de prisión en determinados supuestos, el legislador debería entonces no introducir una nueva sanción penal, sino derogar aquellos institutos que han despojado de contenido rehabilitador a la pena de prisión; particularmente, la dificultad en el acceso al tercer grado y a la libertad condicional, además de facilitar la posibilidad de particular en programas de

\footnotetext{
${ }^{3}$ Cfr. en la Exposición de Motivos del Proyecto de reforma del Código Penal de 2009, p. 3: «Agotada, pues, en estos casos, la dimensión retributiva de la pena, la peligrosidad subsistente del sujeto halla su respuesta idónea en la medida de seguridad, institución que tiene por objeto en nuestro ordenamiento tradicional el tratamiento de las personas peligrosas, que han acreditado tal condición mediante la efectiva realización de un hecho delictivo» (cursiva añadida).

${ }^{4}$ En este mismo sentido, vid. GUDÍN RODRÍGUEZ-MAGARIÑOS, G., La nueva medida de seguridad postdelictual de libertad vigilada: especial referencia a los sistemas de control telemáticos, Ed. Tirant lo Blanch, Valencia, 2012, p. 206; SIERRA LÓPEZ, M., La medida de libertad vigilada, Ed. Tirant lo Blanch, Valencia, 2013, pp. 114-115; HUERTA TOCILDO, S., «Esa extraña consecuencia del delito: la libertad vigilada», en ÁLVAREZ GARCÍA, F. J/et. al. (coords.), Libro homenaje al profesor Luis Rodríguez Ramos, Ed. Tirant lo Blanch, Valencia, 2012, p. 125; PÉREZ BELLO, B., «Ejecución de penas y medidas de seguridad, en especial la libertad vigilada», en Revista Jurídica de Catalunya, núm. 4, 2011, p. 54; MARTÍNEZ GARAY, L., "La libertad vigilada: regulación actual, perspectivas de reforma y comparación fcon la Fürungsaufsicht del Derecho penal alemán", en Revista General de Derecho Penal, núm. 22, 2014, pp. 16-21.
} 
tratamiento. En su lugar, el legislador se escudó en ellos para justificar la aprobación de la nueva medida de seguridad de libertad vigilada.

\section{CONCEPTO Y CONTENIDO DE LA LIBERTAD VIGILADA}

La libertad vigilada es desde la entrada en vigor de la LO 5/2010 la medida de seguridad no privativa de libertad ${ }^{5}$ por excelencia, pues integra muchas de las medidas de seguridad no privativas de libertad que con anterioridad eran configuradas autónomamente. La libertad vigilada, además, es la única medida de seguridad que puede imponerse tanto a sujetos inimputables o semiimputables como también, aunque únicamente en aquellos casos en que así se indique de forma expresa (sistema de imposición específico), a sujetos imputables.

En un primer momento la medida de seguridad de libertad vigilada fue tímidamente introducida frente a los sujetos imputables, pues su imposición únicamente se preveía respecto de los condenados por la comisión de un delito contra la libertad e indemnidad sexual o delitos de terrorismo. Posteriormente, la reforma de 2015 ha terminado por ampliar el catálogo de delitos, aunque en un principio las pretensiones marcadas eran de mayor calado, pues el Proyecto de reforma del Código penal de 2013 pretendía realizar una reforma integral en el sistema de sanciones penales, en el sentido de instaurar un verdadero sistema dualista ${ }^{6}$.

La medida consiste en el sometimiento del condenado a control judicial a través del cumplimiento de alguna o algunas de las obligaciones y prohibiciones que se contemplan en el artículo 106.1 CP por un periodo de tiempo que no podrá ser superior a 5 años (artículo 105.1.a) CP) aunque excepcionalmente frente a determinados sujetos imputables su duración podrá llegar hasta los 10 años (artículos 192.1 y 579.3 CP). Muchas de las obligaciones y prohibiciones que conforman la medida ya estaban previstas, aunque no siempre con idéntica regulación, con anterioridad a la entrada en vigor de la LO 5/2010 como medidas de seguridad no privativas de libertad, penas accesorias, reglas de conducta de la suspensión de la pena o como condiciones de la libertad provisional ${ }^{7}$. Su contenido se concreta con la imposición de una o más de una de las distintas obligaciones y prohibiciones establecidas en el artículo 106.1 CP. El contenido de las mismas es heterogéneo y en muchos casos no implica vigilar al sometido, de modo que cada una de las distintas medidas de libertad vigilada impuestas

\footnotetext{
${ }^{5}$ Aunque alguna sentencia como la SAP de Barcelona (secc. $8^{\text {a }}$ ) 651/2015, 17 de septiembre, indique que impone la «pena» de libertad vigilada.

${ }^{6}$ Vid. Anteproyecto de reforma del Código Penal de 2012. Sobre la propuesta de regulación de libertad vigilada, vid., ACALE SÁNCHEZ, M., "Medidas de seguridad. En especial, la custodia de seguridad", en ÁLVAREZ GARCÍA, F. J. (Dir.), Estudio crítico sobre el anteproyecto de reforma penal de 2012, Valencia, Ed. Tirant lo Blanch, 2013; SANZ MorÁn, Á. J., "Medidas de Seguridad", en ÁLVAREZ GARCÍA, F. J. (Dir.), Estudio crítico sobre el anteproyecto de reforma penal de 2012, cit.,; ZUGALDÍA ESPINAR, J. M., "Medidas de Seguridad", en ÁLVAREZ GARCÍA, F. J. (Dir.), Estudio crítico sobre el anteproyecto de reforma penal de 2012, cit.; SALAT PAISAL, M., «La regulación de la libertad vigilada en la proyectada reforma del Código Penal», en Revista de Derecho y Proceso Penal, núm. 34, 2014; MARTÍNEZ GARAY, L., "La libertad vigilada: regulación actual, perspectivas de reforma y comparación con la Fürungsaufsicht del Derecho penal alemán”, cit.; OTERO GONZÁLEZ, P., La libertad vigilada aplicada a ¿imputables? Presente y futuro, Ed. Dykinson, 2015.

${ }^{7}$ Así lo puso de relieve García AlBERo, R., «De las medidas de seguridad», en Quintero Olivares, G. (Dir.), Comentarios al Código Penal español, cit., p. 688.
} 
a diferentes sujetos puede fácilmente no tener nada que ver con las otras. En concreto, la nueva medida de seguridad está conformada por un total de once obligaciones y prohibiciones que pueden clasificarse en tres grandes grupos ${ }^{8}$ : aquellas que principalmente tienden a controlar la libertad del sometido a la medida, aquellas que principalmente tienden a proteger a terceras personas y aquellas que principalmente tienden a la consecución de fines propiamente correctivos.

Así, entre las obligaciones y prohibiciones tendentes a controlar la libertad del sometido a libertad vigilada encontramos la contenida en la letra a) del art. 106.1 CP. Se trata de una obligación de nueva creación, sin precedentes en el sistema de sanciones español, pues hasta ahora el control a través de medios electrónicos siempre se había configurado como instrumental de otra pena y sin que se estableciera expresamente la obligación de que el seguimiento debiera ser permanente 9 . Por primera vez se obliga al sujeto sometido a soportar un seguimiento constante, continuo, a través del uso de dispositivos electrónicos. La obligación, no obstante, no restringe el derecho a la libertad de circulación (artículo $19 \mathrm{CE}$ ), por lo que con su imposición se es libre de escoger el lugar de residencia o de acudir a cualquier lugar. La segunda de las obligaciones consiste en «la obligación de presentarse periódicamente en el lugar que el juez o tribunal establezca». Tal como se ha indicado por diversos autores ${ }^{10}$, la imposición de esta obligación, dirigida al control del sometido a libertad vigilada, sólo tiene sentido en aquellos casos en que exista riesgo de fuga. Por ello, si ya se hubiere impuesto la obligación de estar siempre localizable, puesto que con ésta ya se controla la libertad de movimientos del sujeto, la imposición de esta segunda obligación no será necesaria ${ }^{11}$. La tercera de las obligaciones tendentes a controlar la libertad del sometido a la medida viene constituida por la obligación «de comunicar inmediatamente, en el plazo máximo y por el medio que el juez o tribunal señale a tal efecto, cada cambio de

\footnotetext{
${ }^{8}$ Cfr. otras clasificaciones realizadas en ACALE SÁNCHEZ, M., «Libertad vigilada», en ÁLVAREZ GARCÍA, F. J./GONZÁLEZ CUSSAC, J. L. (Dirs.), Comentarios a la Reforma Penal de 2010, Ed. Tirant lo Blanch, Valencia, 2010, pp. 152-156; GARCÍA ALBERO, R., «De las medidas de seguridad», en QUINTERO OlIVARES, G. (Dir.), Comentarios al Código Penal español, cit., pp. 688-691; del CARPIO DELGADO, J., «La medida de seguridad de libertad vigilada para delincuentes imputables», en Revista de Derecho Penal y Proceso Penal, núm. 27, 2012, pp. 170-175; OTERO GONZÁLEZ, P., La libertad vigilada aplicada a ¿imputables? Presente y futuro, cit., pp. 96-97.

${ }^{9}$ Acertadamente, vid. TORRES ROSELL, N., «Libertad vigilada y seguimiento continuado de penados: contenido e implicaciones político criminales», en Revista Electrónica de Ciencia Penal y Criminología, 14-06, 2012, p. 12, quien indica en nota a pie de página que «si bien la aplicación de dispositivos telemáticos se prevé en otros preceptos -artículo 48 en relación con las prohibiciones de aproximación a la víctima, 37.4 en el ámbito de la localización permanente, y artículo 86.4 RP para penados en tercer grado penitenciario-, y aun cuando se ha experimentado con este tipo de supervisión en el ámbito de las prohibiciones de aproximación a víctimas de la violencia de género, impuestas tanto como medidas cautelares como penas, lo cierto es que ninguno de los preceptos citados instaba al seguimiento permanente del individuo». Por el contrario, cfr. del CARPIO DELGADO, J., «La medida de seguridad de libertad vigilada para delincuentes imputables», cit., p. 170; SIERRA LÓPEZ, M., La medida de libertad vigilada, cit., p. 124.

10 Vid. ACALE SÁNCHEZ, M., «Libertad vigilada», en ÁLVAREZ GARCÍA, F. J./GONZÁLEZ CUSSAC, J. L. (Dirs.), Comentarios a la Reforma Penal de 2010, cit., p. 152; SIERRA LÓPEZ, M., La medida de libertad vigilada, cit., p. 128.

${ }^{11}$ Coincido, en parte, con la tesis defendida en SIERRA LÓPEZ, M., La medida de libertad vigilada, cit., pp. 124-125, quien considera que la obligación de estar siempre localizable mediante aparatos electrónicos que permitan el seguimiento permanente del sometido a la medida puede llegar a solaparse con otras de las obligaciones de posible imposición que conforman la medida de seguridad de libertad vigilada. No, en cambio, en relación con la obligación de comunicar los cambios del lugar de residencia o de trabajos, pues uno puede cambiar de residencia pero no por el hecho de estar controlado mediante aparatos electrónicos ello puede saberse.
} 
lugar de residencia o del lugar o puesto de trabajo» [artículo 106.1.c) CP]. Tal como sucede en relación con la primera de las obligaciones expuestas, se desprende que, en caso de ser impuesta, únicamente será necesario comunicar — que no solicitar permiso - los cambios de residencia o del lugar o puesto de trabajo en el tiempo y en la forma que así se establezca por parte del juez o tribunal. La referencia del precepto a «comunicar inmediatamente» es superflua, pues si se indica que deberá realizarse en el plazo que se establezca ya se entiende que la comunicación deberá hacerse dentro del mismo y no con posterioridad. La siguiente prohibición que es pertinente incluir dentro de esta clasificación es la de «ausentarse del lugar donde resida o de un determinado territorio sin autorización del juez o tribunal» [artículo 106.1.d) CP]. La prohibición tal como está configurada puede implicar mucho o poco. La cuestión está en determinar qué debe entenderse por «lugar»y «territorio». Dentro de las distintas posibilidades, parece más acorde seguir la interpretación propuesta por ACALE SÁNCHEZ, quien entiende que con «lugar» se quiere delimitar la ciudad y con «territorio» un espacio más amplio, como podría ser una provincia o una comunidad autónoma ${ }^{12}$. No obstante, a pesar de las propuestas doctrinales, deberán ser los juzgados de vigilancia penitenciaria, con el riesgo de que se produzcan criterios dispares, quienes acaben interpretando qué debe entenderse por uno y otro concepto. En todo caso, nunca podrá entenderse por «lugar» el domicilio del sometido a la medida, pues ello sería contrario a la propia naturaleza de la medida de seguridad. La penúltima de las prohibiciones es la contenida en la letra $\mathrm{h}$ ), relativa a la prohibición de residir en determinados lugares ${ }^{13}$. Nuevamente, como sucede con las anteriores prohibiciones mencionadas se plantea el problema de delimitar qué debe entenderse por «lugares». Si se sigue la lógica anterior, éstos deberán referirse a un determinado municipio o ámbito espacial similar. La diferencia reside en que en este supuesto el juez tiene la facultad de prohibir que el sujeto resida no sólo en uno, sino en más de un lugar determinado. La prohibición, no obstante, no limita su derecho a circular libremente por los lugares que se establezcan, sino únicamente a fijar su residencia en $\operatorname{los} \operatorname{mismos}^{14}$. La última de las prohibiciones es la atinente a «desempeñar determinadas actividades que puedan ofrecerle o facilitarle la ocasión para cometer hechos delictivos de similar naturaleza» [artículo 106.1.i) CP].

12 Vid. ACALE SÁNCHEZ, M., «Libertad vigilada», en ÁLVAREZ GARCÍA, F. J./GONZÁLEZ CUSSAC, J. L. (Dirs.), Comentarios a la Reforma Penal de 2010, cit., p. 153; DEL CARPIO DELGADO, J., «La medida de seguridad de libertad vigilada para delincuentes imputables», cit., p. 171; BALBUENA PÉREZ, D., "Algunas consideraciones acerca de la naturaleza, contenido y alcance de la libertad vigilada. ¿medida de seguridad?», en PÉREZ ÁLVAREZ, F. (ED.), Delito, pena, política criminal y tecnologías de la información y la comunicación en las modernas ciencias penales: memorias II Congreso Internacional de Jóvenes Investigadores en Ciencias Penales, cit., pp. 137-138, quien además considera que «la prohibición únicamente estriba en el hecho de desplazarse sin haber solicitado la autorización judicial». sicpep?

${ }^{13}$ La doctrina mayoritaria considera que esta es una prohibición que tiene como finalidad proteger a la víctima. En este sentido, vid. ACALE SÁNCHEZ, M., «Libertad vigilada», en ÁLVAREZ GARCÍA, F. J./GONZÁLEZ CUSSAC, J. L. (DIRS.), Comentarios a la Reforma Penal de 2010, cit., p. 155; SIERRA LÓPEZ, M., La medida de libertad vigilada, cit., p. 132; GARCÍA ALBERO, R., «De las medidas de seguridad», en QUINTERO OLIVARES, G. (Dir.), Comentarios al Código Penal español, cit., p. 690; del CARPIO DELGADO, J., «La medida de seguridad de libertad vigilada para delincuentes imputables», cit., p. 173; BALBUENA PÉREZ, D., «Algunas consideraciones acerca de la naturaleza, contenido y alcance de la libertad vigilada. ¿medida de seguridad?», en PÉREZ ÁLVAREZ, F. (ed.), Delito, pena, política criminal y tecnologías de la información y la comunicación en las modernas ciencias penales: memorias II Congreso Internacional de Jóvenes Investigadores en Ciencias Penales, cit., p. 138. No obstante, su inclusión en este grupo de obligaciones y prohibiciones no parece justificable, pues a diferencia de la prohibición regulada en el art. $48.1 \mathrm{CP}$ aquí no se específica que los lugares prohibidos hayan de ser aquellos en que se haya cometido el delito o resida la víctima o su familia.

${ }^{14}$ En este mismo sentido, vid. SIERRA LÓPEZ, M., La medida de libertad vigilada, cit., p. 131. 
Esta prohibición, de nuevo cuño, no busca tanto controlar la libertad de movimientos del sujeto como evitar que tenga contacto con actividades, ya sean de carácter laboral o lúdico, que puedan incitarle directa o indirectamente a la comisión de nuevos delitos de la misma naturaleza.

El segundo grupo de obligaciones y prohibiciones tiende principalmente a proteger a la víctima del delito cometido, a sus familiares u a otras personas. Por un lado, dentro de este grupo se encuentra la contenida en el artículo 106.1.e) CP, consistente en «la prohibición de aproximarse a la víctima, o a aquellos de sus familiares u otras personas que determine el juez o tribunal». Esta prohibición tiene por objetivo evitar el contacto físico entre el sometido a libertad vigilada y aquellas personas que el juez establezca. Puesto que lo único que se prohíbe es la aproximación física entre los mismos, nada impide que entre ellos puedan comunicarse, como tampoco que el sometido a esta prohibición resida en la misma localidad que la persona a la que se pretende proteger. Por otro lado, la segunda prohibición que debe incluirse es la regulada en el 106.1.f) CP, relativa a "la prohibición de comunicarse con la víctima, o con aquellos de sus familiares u otras personas que determine el juez o tribunal". En este caso, con su imposición se prohíbe que el sujeto sometido a libertad vigilada se comunique con las personas que el juez o tribunal establezcan. A pesar de que el precepto no determine los medios de comunicación prohibidos, no parece necesario que así se disponga. Si el sometido a libertad vigilada no puede comunicarse significa que no puede hacerlo por ningún medio, por tanto no es necesario indicar con qué medios puede o no comunicarse ${ }^{15}$. Por último, como prohibición tendente a la protección de terceras personas, encontramos «la prohibición de acudir a determinados territorios, lugares o establecimientos» [artículo 106.1.g) CP]. Dicha prohibición, que se contemplaba en el anterior artículo 96.3.5. ${ }^{\mathrm{a}} \mathrm{CP}$, ha visto eliminada la concreción de la que gozaba, lo que ha permitido ampliar el abanico de posibilidades en lo que a su imposición se refiere.

Finalmente, el último grupo de obligaciones y prohibiciones que contiene el artículo 106.1 CP está constituido por aquellas cuya finalidad principal es correctiva. Éstas son las contenidas en las letras j) y k) del artículo 106.1 CP. La primera de ellas se refiere a «la obligación de participar en programas formativos, laborales culturales, de educación sexual u otros similares» [artículo 106.1.j) CP]. Con la imposición de esta obligación lo que se pretende es obligar a que el sujeto participe en programas que puedan ser beneficiosos para su reinserción social, de modo que se consiga evitar que vuelva a cometer nuevos delitos en el futuro. El principal problema que se deriva de esta obligación es que en caso de ser impuesta el sometido a la medida está obligado a participar en los programas que así se hayan acordado. No tiene sentido que durante la ejecución de la previa pena privativa de libertad ${ }^{16}$ no quepa imponer coactivamente la obligación de participar en dichos programas, pues la voluntariedad es un principio elemental del tratamiento penitenciario, y, en cambio, finalizada ésta, sí pueda

15 Contrariamente a la opinión defendida, vid. ACALE SÁNCHEZ, M., «Libertad vigilada», en ÁlVAREZ GARCÍA, F. J./GONZÁlEZ CUSSAC, J. L. (Dirs.), Comentarios a la Reforma Penal de 2010, cit., p. 155; SIERRA LÓPEZ, M., La medida de libertad vigilada, cit., p. 130; GARCÍA ALBERO, R., «De las medidas de seguridad», en QUINTERO OLIVARES, G. (Dir.), Comentarios al Código Penal español, cit., p. 689; JIMÉNEZ MARTÍNEZ, C., «La libertad vigilada en el CP de 2010. Especial mención a la libertad vigilada para imputables peligrosos», en Revista de Derecho Penal y Criminología,

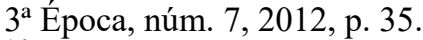

${ }^{16}$ Recuérdese que en el marco de este trabajo solo nos referimos al análisis de la libertad vigilada a sujetos imputables. 
obligarse al sometido a libertad vigilada a participar en ellos ${ }^{17}$. Además, el consentimiento también se requiere para su imposición como pena de trabajos en beneficio de la comunidad y en menor medida cuando es impuesta como regla de conducta de la suspensión de una pena privativa de libertad, pues en estos casos aunque también esté configurada como obligatoria, no es menos cierto que su imposición resulta en un beneficio respecto del cumplimiento de la pena privativa. Asimismo, a diferencia de lo que sucede con la libertad vigilada, la consecuencia de no querer participar en dichos programas puede llegar a suponer, en el caso más grave, la pérdida de dicho beneficio y, consecuentemente, la ejecución de la pena privativa de libertad suspendida. Lo más adecuado hubiera sido que el legislador la configurara como una obligación voluntaria, y en caso de faltar dicho consentimiento pudiera imponerse otra obligación con carácter alternativo a ésta ${ }^{18}$. La segunda y última de las obligaciones es la contenida en el artículo 106.1.k) CP. La obligación contiene a su vez dos obligaciones que pueden imponerse con carácter alternativo. La obligación de seguir tratamiento médico externo y la obligación de someterse a un control médico periódico. Aunque el art. $106 \mathrm{CP}$ nada diga al respecto, en el caso de la obligación de seguir tratamiento médico externo deberá exigirse el consentimiento del sujeto afectado ${ }^{19}$. Es más, en caso de incumplimiento de la obligación de seguir tratamiento médico — que no la obligación de seguir control médico periódico - nunca podrá considerarse que se ha quebrantado la medida de libertad vigilada aunque, eso sí, el juez podrá acordar la sustitución de ésta por otra medida de seguridad (art. 100.3 CP). El primer problema se plantea en relación con los delincuentes imputables, pues no es posible la imposición de otra medida de seguridad distinta de la libertad vigilada. En todo caso, sí que sería posible la modificación de dicha obligación por otra de las contempladas en el artículo 106.1 CP vía artículos 106.3 y $98 \mathrm{CP}$. No obstante, ello implicaría realizar una interpretación extensiva in malam partem del art. $100.3 \mathrm{CP}$, prohibida por el principio de legalidad penal.

Finalmente, es preciso hacer mención a una de las críticas generales en torno al contenido de la libertad vigilada. Esto es, la falta de previsión por parte del legislador de un responsable de ejecución de la medida, que podría denominarse agente de libertad vigilada, encargado de controlar que se cumplan las obligaciones y prohibiciones impuestas y de asistir y apoyar al sujeto sometido a la medida en su resocialización ${ }^{20}$.

\footnotetext{
17 Vid. DE MARCOS MADRUGA, F., «De las medidas de seguridad», en Gómez Tomillo, M. (dir.), Comentarios al Código Penal, Ed. Lex nova, Valladolid, 2011, p. 438; ROCA POVEDA, M., "La libertad vigilada. Notas desde una visión penitenciaria», en La Ley Penal, núm. 96-97, 2012, p. 42.

${ }^{18} \mathrm{Ha}$ de tenerse en cuenta además otro aspecto: el económico. Si el éxito del programa depende de la predisposición a participar en el mismo, en caso que su participación sea impuesta sin el previo consentimiento puede ya pronosticarse que su ejecución supondrá muy probablemente un gasto innecesario. î́

19 De lo contrario se vulneraría las disposiciones contenidas en la Ley 41/2002, de 14 de noviembre, reguladora de la autonomía del paciente, y al derecho constitucional a la dignidad humana.

${ }^{20}$ Vid., entre otros, GUDÍN RODRÍGUEZ-MAGARIÑOS, G., La nueva medida de seguridad postdelictual de libertad vigilada: especial referencia a los sistemas de control telemáticos, cit., pp. 263271; SIERRA LÓPEZ, M., La medida de libertad vigilada, cit., pp. 105-106; VÁZQUEZ GONZÁLEZ, C., "Algunas cuestiones penales y criminológicas sobre la nueva medida de libertad vigilada», en ÁLVAREZ GARCÍA, F. J./et al. (coord.), Libro homenaje al profesor Luis Rodríguez Ramos, Ed. Tirant lo Blanch, Valencia, 2012, pp. 263-264; BOLDOVA PASAMAR, M. A., «Consideraciones políticocriminales sobre la introducción de la libertad vigilada», ReCrim, núm 2, 2009, p. 313; ACALE SÁNCHEZ, M., «Libertad vigilada», en ÁLVAREZ GARCÍA, F. J./GONZÁLEZ CUSSAC, J. L. (Dirs.), Comentarios a la Reforma Penal de 2010, cit., p. 152; MANZANARES SAMANIEGO, J. L., «La libertad vigilada», en Diario La Ley, núm. 7386, 2010, p. 1513; ARMAZA ARMAZA, E. J., El tratamiento penal del delincuente imputable peligroso, Ed. Comares, Granada, 2013, p. 200; MAGRO
} 
Figura que tampoco se ha previsto por el Real Decreto 840/2011, de 17 de junio, por el que se establecen las circunstancias de ejecución de las penas de trabajo en beneficio de la comunidad y de localización permanente en centro penitenciario, de determinadas medidas de seguridad, así como de la suspensión de la ejecución de las penas privativas de libertad y sustitución de penas.

\section{PRESUPUESTOS PARA SU IMPOSICIÓN EN SENTENCIA}

Como se ha indicado supra, la libertad vigilada, como toda medida de seguridad, puede acordarse frente a sujetos declarados inimputables y semiimputables. No obstante, la novedad - y la única perspectiva que se analiza en el trabajo - consiste en el hecho de que la libertad vigilada puede imponerse, junto con una pena privativa de libertad, a sujetos imputables considerados peligrosos. La reforma de la LO 5/2010, empero, configuró dos regímenes distintos de la libertad vigilada: uno para los sujetos inimputables y semiimputables y otro para los imputables. Para los primeros, la regulación de la libertad vigilada es acorde con el sistema de medidas previo a la reforma de 2010.

Frente a sujetos imputables, junto con la imposición de una pena privativa de libertad, deberá acordarse, siempre que así se establezca expresamente, una medida de libertad vigilada para su ejecución posterior a la pena privativa de libertad. La imposición de una pena privativa de libertad es pues requisito sine qua non para la imposición de una medida de seguridad de libertad vigilada, tal como se deriva de lo establecido en el art. 106.2 CP. Contrariando la legislación vigente, la SAP de Cáceres (secc. $2^{\text {a }}$ 349/2014, de 5 de septiembre, acordó en sentencia una medida de seguridad de libertad vigilada a un sujeto imputable junto con una pena de multa lo que supone una vulneración del principio de legalidad. La sentencia ciertamente se dictó en conformidad de las partes pero ello no justifica la posibilidad de imponer una sanción penal que no es posible imponer de acuerdo con el art. 106.2 CP. Más cuando la imposición de la libertad vigilada ya podía imponerse por la condena a otro delito castigado con pena de prisión.

Además de este primer requisito, la libertad vigilada a sujetos imputables sólo puede imponerse en aquellos supuestos en que así se establezca de forma expresa en el Libro II del Código Penal, tal como se indica en el art. 106.2 CP. Se establece, pues, un sistema de imposición específico de la medida. Al respecto, con la introducción de la medida de libertad vigilada, el legislador de 2010 estableció dos supuestos en que es posible la imposición de la libertad vigilada a sujetos imputables. A saber, los sujetos que hayan cometido alguno de los delitos establecidos en el Título VII del Libro II, relativo a los delitos contra la libertad e indemnidad sexuales (ex artículo 192.1 CP), o en el Capítulo VII del Título XXII del Libro II, de las organizaciones y grupos terroristas y de los delitos de terrorismo (ex vigente artículo 579 bis CP).

Además de suponer una novedad el hecho de poder imponer una medida de seguridad a un sujeto imputable, la reforma del Código Penal de 2010 articuló un complejo sistema para determinar en qué casos debe acordarse la medida de seguridad

SERVET, V., «La figura del agente de libertad vigilada en la reforma del código penal», en Diario La Ley, núm. 7074, 2008, passim. 
de libertad vigilada. Lo lógico hubiera sido que, de acuerdo con el artículo 95.1 CP, cometido uno o más delitos por parte de un sujeto imputable, la libertad vigilada debiera imponerse en aquellos casos en que quedase acreditada la peligrosidad criminal del sujeto. No obstante, el legislador optó por introducir una presunción iuris et de iure de peligrosidad criminal de estos sujetos, de modo que la libertad vigilada debe, con carácter general, acordarse obligatoriamente en sentencia. En cambio, será facultativa cuando se trate de delincuentes primarios que cometan un único delito menos grave, por lo que, consecuentemente, en estos casos la libertad vigilada se acordará o no en atención a la peligrosidad del sujeto. Esta presunción de peligrosidad es contraria al sistema de sanciones penales español. Ello supone, con carácter general, que la pena de prisión no sirve $\mathrm{e}^{21}$ para colmar los fines constitucionales que deben perseguir todas las penas y medidas de seguridad ${ }^{22}$. Luego, frente a las deficiencias que presenta la ejecución de la pena es necesario añadir una nueva sanción penal, configurada ahora como medida de seguridad, para rehabilitar a los que no han sido rehabilitados en el lugar donde debiera haberse realizado. Si se considera que la pena de prisión no tiene materialmente efectos preventivo-especiales ¿por qué no se procura mejorar el régimen de ejecución de las penas? ${ }^{23}$ En su lugar, el legislador acepta que las penas de prisión no están funcionando, pero en vez de buscar una solución en sede de la propia pena de prisión, opta por incrementar la condena penal impuesta, dejando así el cumplimiento de la función rehabilitadora que proclama la Constitución para una ulterior etapa, una vez cumplida la pena privativa de libertad ${ }^{24}$.

La presunción por parte del legislador de la peligrosidad de un sujeto por el mero hecho de haber cometido un determinado tipo de delito ha sido muy criticada por

\footnotetext{
${ }^{21} \mathrm{Y}$ así lo refuerza el hecho de que la Exposición de Motivos de la LO 5/2010, cuando justifica la necesidad de introducir la libertad vigilada, establece que «en determinados supuestos de especial gravedad ese efecto rehabilitador de la pena se ve dificultado, en la medida en que ésta no resulta suficiente o adecuada para excluir un elevado riesgo de reincidencia».

${ }^{22}$ De esta opinión, vid. FEIJOO SÁNCHEZ, B., «La libertad vigilada en el derecho penal de adultos», en DÍAZ-MAROTO VILLAREJO, J. (dir.), Estudios sobre las reformas del Código penal operadas por las LO 5/2010, de 22 de junio, y 3/2011, de 28 de enero, Ed. Civitas, Madrid, 2011, p. 215.

${ }^{23}$ Vid. CID MOLINÉ, J. / TÉBAR VILCHES, B., "Libertad condicional y delincuentes de alto riesgo", en Revista Española de Investigación Criminológica, núm. 8, 2010, quienes concluyen que el conjunto de mecanismos de transición entre la situación de prisión y la plena libertad (los permisos, el régimen abierto y la libertad condicional, por citar los más importantes) son efectivos en la reducción de los índices de reincidencia.

${ }^{24}$ Vid. ACALE SÁNCHEZ, M., «Libertad vigilada», en ÁLVAREZ GARCÍA, F. J./GONZÁLEZ CUSSAC, J. L. (dirs.), Consideraciones a propósito del Proyecto de Ley de 2009 de modificación del Código Penal, Ed. Tirant lo Blanch, 2010, p. 155; JIMÉNEZ MARTÍNEZ, C., «La libertad vigilada en el $\mathrm{CP}$ de 2010. Especial mención a la libertad vigilada para imputables peligrosos», cit., p. 39. Cfr. en BENÍTEZ ORTÚZAR, I., «La nueva «medida de seguridad» de «libertad vigilada» aplicable al sujeto imputable tras el cumplimiento de la pena privativa de libertad. La admisión de los postulados del «derecho penal del enemigo» por la LO 5/2010», en Cuadernos de Política Criminal, núm. 103, 2011, p. 124, quien textualmente indica: «Realmente, la "libertad vigilada" como «medida de seguridad» de ejecución posterior al cumplimiento de la pena, parte de una completa renuncia de la función preventivo especial de la pena, reduciendo la misma a su función exclusivamente retributiva (que, indirectamente, puede desarrollar efectos de prevención general intimidatoria) por el hecho delictivo cometido haciendo subsistir, de este modo, la "peligrosidad" del sujeto que, tras el «abono» de la culpabilidad se ve sometido a una "normas de conducta" de forma coactiva. [...] las medidas asegurativas y prohibitivas en que se concreta la libertad vigilada, aún revestida del carácter de medida de seguridad, también aparecen dirigidas primordialmente hacia una finalidad de defensa social y de protección a las víctimas (potenciales, es decir, ¿futuras e inciertas?), en lugar de a una finalidad prioritariamente preventivo especial, tal y como correspondería a una consecuencia jurídica del delito que se encuadra entre las que aparecen con la naturaleza jurídica de medidas de seguridad».
} 
la doctrina científica al vulnerarse los principios generales de imposición de medidas de seguridad, pues, en todo caso, su fundamento debería encontrarse en la peligrosidad criminal del autor (artículos 6.1 y 95.1 CP) y no en el mero hecho de haber cometido una determinada tipología delictiva ${ }^{25}$. En todo caso, al igual que sucede en los supuestos de imposición de la medida de libertad vigilada a sujetos inimputables o semiimputables, es en el momento de dictar sentencia condenatoria cuando debería comprobarse si existe fundamento para la imposición de la medida de seguridad, de modo que revelada la peligrosidad criminal se impondría la misma, y ésta se ejecutaría junto con la pena de prisión. Posteriormente, justo en el momento anterior a la extinción de la pena de prisión - que no de la condena, puesto que la libertad vigilada forma parte de la misma ${ }^{26}$ - debería comprobarse si persiste o no dicha peligrosidad derivada del hecho cometido, con el fin de prolongar su duración. Además, el hecho de presumir, en el momento de dictar sentencia, una peligrosidad criminal respecto de determinados sujetos puede plantear la duda de si la peligrosidad criminal que presenta el sujeto una vez cumplida la pena de prisión se debe al hecho delictivo o al tiempo que ha pasado privado de libertad, de modo que no sea posible conocer el origen temporal de la misma. Consecuentemente, en aquellos casos en que la peligrosidad criminal no parta de un suceso delictivo previo la libertad vigilada debería ser considerada como predelictual y por tanto inconstitucional.

Como se ha dicho, la LO 5/2010 estableció que la imposición de la libertad vigilada frente a sujetos imputables únicamente era potestativa, y por tanto se hacía depender -como debería ser en todo caso- de la peligrosidad criminal del sujeto en aquellos casos en que un delincuente primario cometiera un único delito de carácter sexual o de terrorismo calificado de menos grave ${ }^{27}$. Por tanto, para determinar la

${ }^{25}$ En este sentido, vid. GARCÍA ALBERO, R., «De las medidas de seguridad», en QUINTERO OLIVARES, G. (Dir.), Comentarios al Código Penal español, cit., p. 687; SANZ MORÁN, A. J., «Libertad vigilada y quebrantamiento de condena: artículos 106 y 468 CP», en ÁLVAREZ GARCÍA, F. J./GONZÁLEZ CUSSAC, J. L. (dirs.), Consideraciones a propósito del Proyecto de Ley de 2009 de modificación del Código Penal, cit., p. 143; SANZ MORÁN, A. J., «La nueva medida de libertad vigilada: reflexión político-criminal», en MUÑOZ CONDE, F., et al. (dirs.), Un Derecho penal comprometido. Libro homenaje al Prof. Dr. Gerardo Landrove Díaz, cit., pp. 1019-1020; TAMARIT SUMALLA, J. M., «Delitos relativos a la pornografía infantil y otras medidas relacionadas con la delincuencia sexual, artículos 189 y 192 CP», en QUINTERO OLIVARES, G. (dir.), La reforma penal de 2010: análisis y comentarios, Ed. Aranzadi, Cizur Menor, 2010, p. 178; ACALE SÁNCHEZ, M., «Libertad vigilada», en ÁLVAREZ GARCÍA, F. J./GONZÁLEZ CUSSAC, J. L. (dirs.), Consideraciones a propósito del Proyecto de Ley de 2009 de modificación del Código Penal, cit., p. 156, quien considera que «se trata de una muestra de «derecho penal de autores», que se dirige a no ciudadanos individuales que cometan delitos, sino a "grupos de delincuentes"»; CÓRDOBA RODA, J., «Prescripción del delito, libertad vigilada y comiso», en Revista Jurídica de Catalunya, vol. 110, núm. 4, 2011, pp. 907-908. Contrariamente a la opinión mayoritaria, vid. FEIJOO SÁNCHEZ, B., «La libertad vigilada en el derecho penal de adultos», en DÍAZ-MAROTO VILLAREJO, J. (dir.), Estudios sobre las reformas del Código penal operadas por las LO 5/2010, de 22 de junio, y 3/2011, de 28 de enero, cit., p. 220, quien considera que simplemente es «un presupuesto para permitir un posterior juicio de peligrosidad en el momento en el que se esté terminando de cumplir la pena de prisión. En el fondo no se trata más que de una formalidad para dejar claro que la libertad vigilada es una medida de seguridad postdelictiva que, si se impone, está vinculada a la peligrosidad manifestada en un hecho delictivo previo».

${ }^{26}$ Cfr. VÁZQUEZ GONZÁLEZ, C., «Algunas cuestiones penales y criminológicas sobre la nueva medida de libertad vigilada», en ÁLVAREZ GARCÍA, F. J./et al. (coord.), Libro homenaje al profesor Luis Rodríguez Ramos, cit., pp. 252-253, quien considera que una vez cumplida la pena de prisión se cumple la condena pero que incluso así es posible la imposición posterior de la libertad vigilada. is.pip

${ }^{27}$ Cfr. BALBUENA PÉREZ, D., «Algunas consideraciones acerca de la naturaleza, contenido y alcance de la libertad vigilada. ¿medida de seguridad?», en PÉREZ ÁLVAREZ, F. (ed.), Delito, pena, política criminal y tecnologías de la información y la comunicación en las modernas ciencias penales: memorias 
obligatoriedad o no de la imposición de la libertad vigilada a sujetos imputables deberá determinarse la gravedad del delito cometido, el número de delitos perpetrados y los antecedentes penales del condenado.

Para determinar la gravedad del delito cometido primero debe acudirse a la gravedad de la pena prevista por el delito en abstracto, por lo que es preciso determinar qué debe entenderse por pena en abstracto. Ante todo debe advertirse que no puede entenderse, como así han hecho algunos tribunales, aquella que efectivamente se acaba imponiendo en sentencia. En este sentido, la SAP de Zamora (secc. 1 ${ }^{\text {a }}$ ) 27/2015, de 8 de octubre, o la SAP de Madrid (secc. 6 ${ }^{a}$ ) 618/2015, de 11 de septiembre, adoptan como baremo para determinar la gravedad del delito cometido la pena impuesta en el fallo de la sentencia, de modo que en ambos casos la pena que acaba imponiéndose es una pena inferior a cinco años y por tanto menos grave, a pesar de que en ambos casos los delito cometidos eran en abstracto graves.

Donde la respuesta no es tan sencilla es en determinar si la pena en abstracto es aquella contenida en todo caso en la parte especial del Código Penal o aquella que resulta aplicable para el concreto tipo delictivo y frente al sujeto que se está juzgando, de acuerdo con las reglas de imposición de las penas establecidas en la parte general del Código. Sobre este extremo los tribunales españoles han dictado sentencias contradictorias. Así, la SAP de Barcelona (secc. 20a) 509/2015, de 1 de julio, en un caso de tentativa de violación, decide reducir la pena en dos grados. Sin embargo, para determinar la gravedad del delito cometido no tiene en cuenta el grado de ejecución del tipo, lo que provocaría que el delito fuera considerado menos grave, sino la pena prevista en el art. 179 CP por el delito de violación consumado. En el polo opuesto, la SAP de Barcelona (secc. $6^{a}$ ) 167/2014, de 24 de febrero, tiene en cuenta para la determinación de la pena en abstracto la que resulta de aplicar la circunstancia atenuante de reparación del daño, de modo que la pena resultante en el delito de abusos sexuales a menores de trece años no es de dos a seis años, sino de dos a cuatro años de acuerdo con el art. 33.3 CP como una pena menos grave. Así considerada, la libertad vigilada es pues de imposición potestativa, por lo que el tribunal, ante la falta de apreciación de peligrosidad criminal del acusado, decide no imponer la medida de libertad vigilada. Igualmente, la SAP de Granada (secc. $2^{a}$ ) 477/2015, de 15 de julio, que para determinar la gravedad de la pena en abstracto tiene en cuenta la concurrencia de la atenuante de confesión y la atenuante de reparación del daño, lo que provoca que el delito de abusos sexuales a menores previsto en el art. $183 \mathrm{CP}$ por el que se condena al acusado pase de delito grave a menos grave. Finalmente, en un punto intermedio, la SAP de Lleida (secc. $1^{\mathrm{a}}$ ) 72/2014, de 10 de marzo, ante la comisión de un delito de violación en grado de tentativa con la apreciación de la atenuante analógica de enfermedad mental, acaba imponiendo una medida de libertad vigilada con carácter preceptivo con una duración de siete años. Para ello, el tribunal tuvo en cuenta que el delito únicamente fue intentado y por tanto la pena abstractamente aplicable era la establecida en la parte especial rebajada en un grado (de tres a seis años).

La respuesta más correcta debe situarse en la última de las tesis; la que es defendida por la SAP de Lleida. La pena prevista en la parte especial del Código es la pena en abstracto para el delito consumado cometido por el autor. Por tanto, en aquellos

II Congreso Internacional de Jóvenes Investigadores en Ciencias Penales, cit., pp. 134-135, quien considera que incluso en estos casos es posible imponer la libertad vigilada aunque no quede acreditada la peligrosidad criminal del autor. '[SEE⿱乛龰? 
casos en que se plantee la pena en abstracto del partícipe, de un delito intentado o incluso de un acto preparatorio la pena en abstracto de aquel delito no será la establecida en el Libro II, sino la resultante de aplicar las reglas previstas en la parte general. Igualmente, en aquellos casos en que concurra una causa de justificación que conlleve la aplicación de una eximente incompleta ésta deberá tenerse en cuenta para determinar la gravedad del delito, pues a efectos de antijuridicidad de la conducta la gravedad de la misma habrá cambiado. Otra cosa es tener en cuenta para la determinación de la pena en abstracto aquellas eximentes o atenuantes que afectan a la culpabilidad o a circunstancias personales del condenado. La concurrencia de éstas no debe tenerse en cuenta, pues no afectan a la gravedad del delito, sino que lo que provocan es una modulación de la pena a imponer a ese concreto sujeto, sin que la calificación del hecho cometido sufra alteración alguna.

En cuanto al número de delitos cometidos, no se entenderá que se ha cometido un solo delito cuando sea condenado por un delito continuado o un concurso de delitos o incluso por un concurso ideal de delitos. De hecho, en los supuestos en que uno es condenado por un concurso ideal de delitos ha cometido más de un delito, por más que el Código Penal establezca una regla de determinación que resulte en la imposición de una única sanción ${ }^{28}$. Más evidente resulta todavía el hecho de que la aplicación de las reglas penológicas del concurso medial o real de delitos o del delito continuado no implica que se haya cometido un único delito.

En cuanto al último de los criterios que el juzgador debe tener en cuenta a la hora de determinar la preceptividad o no de la imposición de la medida de seguridad, la primariedad delictiva debe entenderse referida a que el sujeto condenado no tenga antecedentes penales por la comisión de cualquier delito, a excepción que sean cancelados o cancelables ${ }^{29}$. En estos casos, la libertad vigilada se impondrá cuando así se considere necesario para hacer frente a la peligrosidad criminal del autor. Por tanto,

\footnotetext{
${ }^{28}$ Contrariamente, cfr. TAMARIT SUMALLA, J. M., «Delitos relativos a la pornografía infantil y otras medidas relacionadas con la delincuencia sexual, artículos 189 y 192 CP», en QUINTERO OLIVARES, G. (dir.), La reforma penal de 2010: análisis y comentarios, cit., p. 179, quien considera que ante estos supuestos debería interpretarse como un único delito.

${ }^{29}$ La doctrina discute acerca de que debe interpretarse por delincuente primario. Para algunos delincuente primario es aquel que no tiene antecedentes penales o que teniéndolos hayan sido o pueden haber sido cancelados, y para otros es aquel «no reincidente». Aunque me parecería más razonable (más aún eliminar la obligatoriedad de su imposición) que el legislador hubiera optado por establecer como requisito no ser reincidente, la verdad es que no lo ha hecho y por tanto solo queda interpretar como primario aquel que comete un delito por primera vez. Vid., en el mismo sentido defendido aquí, TAMARIT SUMALLA, J. M., «Delitos relativos a la pornografía infantil y otras medidas relacionadas con la delincuencia sexual, artículos 189 y 192 CP», en QUINTERO OLIVARES, G. (dir.), La reforma penal de 2010: análisis y comentarios, cit., p. 179; GARCÍA ALBERO, R., «De las medidas de seguridad», en QUINTERO OLIVARES, G. (Dir.), Comentarios al Código Penal español, cit., p. 692. Favorables a interpretar delincuente primario como «no reincidente», CID MOLINÉ, J., «La medida de seguridad de libertad vigilada (artículos 106 CP y concordantes)», en SILVA SÁNCHEZ, J. M. (dir.), El nuevo Código Penal. Comentarios a la reforma, Ed. La Ley, Madrid, 2012, p. 195; FEIJOO SÁNCHEZ, B., «La libertad vigilada en el derecho penal de adultos», en DÍAZ-MAROTO VILLAREJO, J. (dir.), Estudios sobre las reformas del Código penal operadas por las LO 5/2010, de 22 de junio, y 3/2011, de 28 de enero, cit., p. 220; GÓMEZ MARTíN, V., «La reforma de la parte general del código penal (Lo 5/2010, de 22 de junio): ¿avance o retroceso?», en Revista Catalana de Seguretat Pública, núm. 27, 2011, p. 181; GARCÍA RIVAS, N., «La libertad vigilada y el derecho penal», en DEMETRIO CRESPO, E. (dir.), Neurociencias y derecho penal. Nuevas perspectivas en el ámbito de la culpabilidad y tratamiento jurídico penal de la peligrosidad, Ed. Edisofer, Madrid, 2013, p. 603. Igualmente, aunque no se inclina por esta posibilidad con tanta rotundidad, vid. ACALE SÁNCHEZ, M., Medición de la respuesta punitiva y Estado de Derecho, Ed. Aranzadi, Cizur Menor, 2011, p. 190.
} 
los tribunales, en la sentencia condenatoria deberán indicar las razones por las que consideran que debe o no debe imponerse la libertad vigilada. A pesar de ello, son múltiples las sentencias que en estos casos acaban imponiendo la libertad vigilada sin justificación alguna. Así, las SSAP de Barcelona (secc. 3 $3^{\text {a }}$ 628/2015, de 13 de octubre, Valladolid (secc. 4a) 294/2015, de 24 de septiembre, Oviedo (secc. $3^{\text {a }}$ ) 511/2015, de 14 de diciembre, Zaragoza (secc. 6 ${ }^{\text {a }}$ 306/2015, de 18 de noviembre, Barcelona (secc. 2) 686/2015, de 9 de septiembre y la de Barcelona (secc. 22) 372/2015, de 8 de julio o la SAP de Madrid (secc. $7^{\text {a }}$ ) 840/2015, de 23 de octubre, que decide no imponer la libertad vigilada sin que tampoco pueda vislumbrarse justificación alguna de su decisión.

Por tanto, en aquellos supuestos en que no se cumplan los mencionados requisitos - a saber, delito menos grave, comisión de un único delito y primariedad delictiva - la medida de seguridad de libertad vigilada es de preceptiva imposición. No acordarla vulnera el derecho positivo español, a pesar de que los motivos para no hacerlo sean del todo loables. En este sentido, la SAP de Murcia (secc. $3^{\text {a }}$ ) 397/2015, de 22 de septiembre, ante la condena por la comisión de un delito de carácter sexual grave decide no imponer la medida de libertad vigilada atendiendo al hecho que junto con la pena de diez años de prisión se imponían ya las penas accesorias de prohibición de aproximación y comunicación. Luego, el tribunal consideró que no concurrían motivos suficientes que justificaran la imposición de la libertad vigilada en atención a criterios de prevención especial.

Podría considerarse, a pesar de ser legalmente obligatoria la imposición de la libertad vigilada según lo establecido en el art. 106 CP y arts. 192 o 579 bis CP, no acordarla en sentencia en aquellos casos en que sea patente la no concurrencia del requisito de la peligrosidad criminal exigido por el art. $95 \mathrm{CP}$, pues, a pesar de todo, la libertad vigilada es una medida de seguridad y como tal sometida al régimen general de las mismas. En todo caso, deberá entenderse que no será posible la imposición de la libertad vigilada, por faltar el requisito de la peligrosidad, en aquellos casos en que la ejecución de la pena de prisión sea suspendida o sustituida ${ }^{30}$. Esta posición no es, empero, la defendida por la jurisprudencia. En este sentido, la STS (sala $2^{a}$ ) 768/2014, de 11 de noviembre. La sentencia estima adecuado imponer la libertad vigilada junto con una pena susceptible de suspensión, pero además abre la puerta a la posibilidad de que incluso suspendida la pena se acabe ejecutando la medida de libertad vigilada, al establecer en el último de los fundamentos que «aunque muy similares, no son idénticos los contenidos eventuales de una libertad vigilada y de las condiciones previstas como regla de conducta en el art. $83 \mathrm{CP}$ ». En semejantes términos, la SAP de Valladolid (secc. $2^{\text {a }}$ ) 305/2015, de 23 de noviembre, que acuerda imponer una medida de seguridad de libertad vigilada por un periodo de 5 años junto con una pena de prisión que acuerda suspenderse, por conformidad de las partes, en la misma sentencia condenatoria.

La reforma operada mediante la LO 1/2015 introduce dos nuevos artículos, el 140 bis y el 156 ter CP, a la vez que modifica el apartado 2 del artículo 173 con el objetivo de facultar la imposición de una medida de libertad vigilada a los sujetos imputables condenados por la comisión de alguno de los delitos establecidos en los mismos. Por una parte, el nuevo artículo 140 bis CP establece que a los sujetos condenados por la comisión de uno o más delitos comprendidos en el Título I del Libro

\footnotetext{
${ }^{30}$ Vid. CID MOLINÉ, J., «La medida de seguridad de libertad vigilada (artículos $106 \mathrm{CP}$ y concordantes)», en SILVA SÁNCHEZ, J. M. (dir.), El nuevo Código Penal. Comentarios a la reforma, cit., p. 195; SIERRA LÓPEZ, M., La medida de libertad vigilada, cit., p. 149. iș̣p?
} 
II (del homicidio y sus formas) se les podrá imponer, junto con la respectiva pena, una medida de libertad vigilada. Debe criticarse duramente la regulación del artículo 140 bis $\mathrm{CP}$, pues, aunque posiblemente el legislador estuviera pensando únicamente en los delitos tipificados sistemáticamente con anterioridad al artículo 140 bis -homicidio doloso y asesinato-, se permite también la imposición de la libertad vigilada ante la comisión de un delito de homicidio imprudente o de inducción al suicidio. Por otra parte, el artículo 156 ter $\mathrm{CP}$ faculta al juez o tribunal sentenciador a imponer, junto con una pena de prisión, la medida de seguridad de libertad vigilada en aquellos casos en que el sujeto activo del delito cometa un conducta tipificada en el Título III, relativo a los delitos de lesiones, siempre y cuando la víctima del delito sea alguna de las contenidas en el artículo $173.2 \mathrm{CP}$; esto es, cónyuge, ex cónyuge o análogo y los ascendientes, descendientes y demás miembros de la unidad familiar o bajo custodia o guarda del agresor. Finalmente, la reforma modifica el artículo $173.2 \mathrm{CP}$ in fine en el sentido de establecer la posibilidad de imponer, con carácter potestativo, una medida de libertad vigilada a los sujetos condenados por la comisión de un delito de maltrato habitual. En estos casos, el legislador ha configurado la medida de seguridad como potestativa, de modo que únicamente será posible su imposición en aquellos supuestos en que se acredite el requisito de la peligrosidad criminal establecido en el art. $95 \mathrm{CP}$. Contrariamente, la SAP de Barcelona 47/2015, de 27 de noviembre, impone una medida de seguridad de libertad vigilada a un sujeto condenado por un delito de homicidio sin justificación alguna de su necesidad.

Así, tras la reforma del Código Penal de 2015 pueden diferenciarse dos regímenes de imposición distintos de la medida de libertad vigilada a sujetos imputables: el creado por la LO 5/2010, por el que se establece, excepto cuando se comete un único delito menos grave por un delincuente primario, un régimen preceptivo de imposición aplicable a sujetos que hayan cometido un delito contra la libertad e indemnidad sexuales o de terrorismo; y uno nuevo, introducido por la LO 1/2015, en que su imposición debe articularse en todo caso como potestativa.

Una vez acordada la obligatoriedad o la necesidad de la imposición de la libertad vigilada en sentencia solo es posible acordar, a pesar del número de delitos cometidos, una única medida de seguridad. No es correcto pues el fallo de la anteriormente citada SAP de Cáceres 349/2014 que acuerda tantas medidas de libertad vigilada como delitos ha cometido el condenado. Así, la sentencia, impone una primera libertad vigilada de 2 años de duración por un delito de online child grooming y otra medida de libertad vigilada de 5 años de duración por la comisión de un delito de abusos sexuales a menores de 13 años. Tampoco, el de las SAP de Barcelona (secc. 9a) 304/2015, de 1 de abril, la SAP de Córdoba (secc. $3^{\text {a }}$ ) 365/2015, de 23 de julio y la SAP de Palma de Mallorca (secc. $2^{\mathrm{a}}$ ), de 10 de julio. En todas ellas se imponen tantas medidas de libertad vigilada como número de delitos por el que han sido condenados. A pesar de que el art. 106.2 CP haga referencia a la posibilidad de cumplir con distintas medidas de seguridad de libertad vigilada, ésta se refiere a los supuestos en que han sido impuestas en el seno de distintos procesos penales. La posición defendida queda confirmada por lo establecido en la parte especial del Código, pues en aquellos supuestos en que es posible la imposición de la libertad vigilada a sujetos imputables se establece que se impondrá además la medida de libertad vigilada y no la medida o medidas de libertad vigilada. Así por ejemplo, el art. 192.1 CP establece: "A los condenados a pena de prisión por uno o más delitos $[\ldots]$ se les impondrá además una medida de libertad vigilada [...]". 
La libertad vigilada tiene, con carácter general, una duración máxima de cinco años. No obstante, cuando resulte aplicable a sujetos imputables - no a inimputables o semiimputables - que han cometido un delito de carácter sexual o de terrorismo - no el resto de delitos - su duración se duplica, de modo que puede llegar a los diez años ${ }^{31}$. Así, en los primeros, cuando se cometa uno o más delitos menos graves, la libertad vigilada tendrá una duración de uno a cinco años y en caso de cometer un delito grave la medida tendrá una duración de cinco a diez años. En cambio, respecto a los que cometan delitos de terrorismo, la duración de la libertad vigilada se hace depender de la gravedad de la pena impuesta, lo que conlleva que aunque no se haya cometido ningún delito grave es posible que se imponga una medida de libertad vigilada con una duración de entre cinco y diez años ${ }^{32}$. Ello será así cuando ante la comisión de un solo delito castigado con una pena de prisión de hasta cinco años sea de aplicación la agravante de reincidencia cualificada. En el resto de supuestos en que es posible la imposición de la libertad vigilada a sujetos imputables (delitos contra la vida, de lesiones o de malos tratos) ésta tendrá una duración máxima de cinco años, y en ningún caso podrá ampliarse a los diez. Debe criticarse, de nuevo, este doble régimen entre unos y otros tipos de delincuentes, sobre todo cuando en el caso de delitos tan graves como son contra la propia vida no es posible la imposición de la medida de libertad vigilada por un periodo superior a cinco años pero sí en cambio por la comisión de un delito de pornografía infantil. Debe igualmente criticarse que se haya establecido un límite inferior fijado en un año. Como toda medida de seguridad, su duración no puede basarse en criterios de prevención general o retributivos, sino en razones de prevención especial, por lo que no tiene sentido fijar límites mínimos en ningún caso. Además, de nuevo, este límite inferior solo se contempla respecto de los sujetos que cometan uno o más delitos contra la libertad e indemnidad sexual o de terrorismo, pero no respecto del resto.

Determinada la duración en abstracto de la medida de libertad vigilada, para el supuesto de sujetos imputables, los tribunales deberán determinar en sentencia su duración. Supone una vulneración del principio de legalidad, pues, la imposición la libertad vigilada sin concretar el tiempo por el que el sujeto deberá estar sometido a la misma. En este sentido, deben criticarse, pues, la SAP de Madrid (secc. $5^{a}$ ) 79/2015, de 7 de octubre, la SAP de Valladolid (secc. $4^{\text {a }}$ ) 294/2014, de 24 de septiembre y la STS (sala $2^{a}$ ) 76/2015, de 23 de noviembre, que acepta un recurso de casación y consecuentemente modifica la pena e impone una medida de libertad vigilada sin determinar la duración de la misma.

\section{LA DETERMINACIÓN JUDICIAL DEL CONTENIDO DE LA MEDIDA Y SU RÉGIMEN DE EJECUCIÓN}

\footnotetext{
${ }^{31}$ Vid. auto del TS (sala de lo penal), 1270/2014, de 10 de julio, en el que se constata como la audiencia provincial de Sevilla condenó a un individuo a, entre otras penas, una medida de libertad vigilada de 12 años, lo que supera a la duración permitida por ley.

${ }^{32}$ Cfr. en GARCÍA RIVAS, N., «La libertad vigilada y el derecho penal», en DEMETRIO CRESPO, E. (dir.), Neurociencias y derecho penal. Nuevas perspectivas en el ámbito de la culpabilidad y tratamiento jurídico penal de la peligrosidad, cit., p. 603, quien considera que en ambos supuestos la duración de la medida de libertad vigilada se hace depender de la gravedad de la pena prevista en el código para el delito que se trate. in
} 
Otra particularidad de la libertad vigilada cuando se impone a sujetos imputables es que, aunque su imposición debe realizarse en la sentencia condenatoria, su ejecución queda suspendida hasta el cumplimiento de la pena de prisión que le haya sido impuesta, momento en el que se decidirá si la medida debe activarse y, en caso afirmativo, qué concretas obligaciones y prohibiciones se imponen al sometido a libertad vigilada. Dicha particularidad, que queda claramente plasmada en el apartado $2^{\circ}$ del art. $106 \mathrm{CP}$, ha sido objeto de controversia en la jurisprudencia menor. Así, entre otras, las SSAP de Cáceres 349/2014, de 5 de septiembre, de Lugo (secc. 2a) 133/2014,

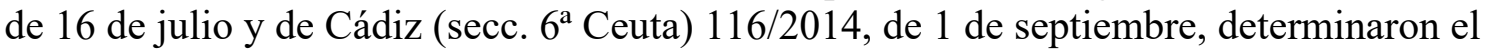
contenido de la medida en la propia sentencia condenatoria. Ha tenido que ser el Tribunal Supremo quien, en su conocida STS 768/2014, de 11 de noviembre, ha aclarado algo que en la doctrina era una cuestión pacífica: que en el momento de imponer la libertad vigilada no debe concretarse su contenido, sino que ello debe realizarse en un momento posterior, antes de la extinción de la pena privativa de libertad y de acuerdo con lo establecido en el art. 106.2 CP. No obstante, incluso con posterioridad a la citada sentencia del TS y también de otras posteriores que ha dictado el Alto Tribunal, diferentes audiencias provinciales continúan fallando en el sentido de determinar en sentencia el contenido. Así, durante el segundo semestre del 2015, las SSAP de Madrid (secc. 16 $6^{a}$ ) 707/2015, de 20 de octubre, de Madrid (secc. 5a) 79/2015, de 7 de octubre, de Madrid (secc. 16 $6^{\text {a }} 740 / 2015$, de 8 de julio, de Valencia (secc. $2^{\mathrm{a}}$ ) 984/2015, de 15 de diciembre, de Valencia (secc. $5^{\text {a }}$ ) 642/2015, de 20 de septiembre, de Valencia (secc. 4a) 476/2015, de 8 de julio, de Oviedo (secc. $3^{\mathrm{a}}$ ) 511/2015, de 14 de diciembre, de Barcelona 47/2015, de 27 de noviembre, de Ávila (secc. $1^{\text {a }}$ ) 164/2015, de 27 de noviembre, de Valladolid (secc. $2^{\text {a }}$ ) 305/2015, de 23 de noviembre, de Zaragoza (secc. 6a) 306/2015, de 18 de noviembre, de Albacete (secc. $2^{\mathrm{a}}$ ) 281/2015, de 16 de julio y la de Mérida (secc. $3^{\text {a }}$ ) 194/2015, de 9 de julio, acuerdan en la propia sentencia condenatoria el contenido de la libertad vigilada. Paradojalmente, la SAP de Badajoz (secc. $1^{\text {a }}$ ) 33/2015, de 22 de septiembre, frente a un sujeto semiimputable impone una medida de libertad vigilada sin establecer el contenido concreto. En este caso, no rige lo establecido en el apartado $2^{\circ}$ del art. $106 \mathrm{CP}$, por lo que el tribunal debiera haber concretado qué obligaciones y prohibiciones debían imponerse.

Según el artículo 23 RD 840/2011 y la instrucción 19/2011, de la Secretaría General de Instituciones Penitenciarias, relativa al cumplimiento de las medidas de seguridad competencia de la administración penitenciaria, la Junta de Tratamiento $\mathrm{u}$ órgano autonómico equivalente del Centro Penitenciario en el que el penado se encuentre cumpliendo condena, o del que esté adscrito si se encuentra en libertad condicional, tres meses antes de la extinción de la pena privativa de libertad y a solicitud del JVP, elevará a éste un informe técnico sobre la evolución del penado en el que se propondrán de forma motivada las obligaciones y prohibiciones concretas a las que debería ser sometido el condenado a libertad vigilada. De acuerdo con dicho informe técnico, el JVP deberá decidir si procede iniciar la ejecución de la libertad vigilada o no. Para ello, deberá tenerse en cuenta, según el informe técnico elaborado, el grado de rehabilitación y el pronóstico de reincidencia del concreto sujeto. En caso afirmativo, se determinarán las concretas obligaciones y prohibiciones que se imponen al sujeto. Conforme a la propuesta del JVP, el juez o tribunal sentenciador resolverá de forma motivada, oída la propia persona sometida a la medida, el Ministerio Fiscal y las demás partes, como puede ser la víctima del delito. 
Junto a ello, el artículo 106.2 CP prevé que en el caso que se hubieren impuesto varias penas privativas de libertad, a efectos de determinar el momento en que debe acordarse si se da inicio o no a la medida de libertad vigilada, se entenderá que todas ellas son una sola pena. Además se prevé el supuesto en que al sujeto se le hayan impuesto diversas medidas de libertad vigilada. En estos casos, la regla general es que si son compatibles se cumplirán de forma simultánea, y si son incompatibles de forma sucesiva, sin perjuicio del proceso simplificado de modificación del contenido de la libertad vigilada.

Como se ve, el texto final de la LO 5/2010 no ha tenido en consideración las objeciones que el CGPJ y el Ministerio Fiscal en sus preceptivos informes al Anteproyecto de reforma del Código Penal de 2008 realizaron sobre la posibilidad de que se impusiera la libertad vigilada ante sujetos que han cumplido la última parte de la pena de prisión en tercer grado penitenciario o en libertad condicional ${ }^{33}$. Es evidente que aquellos supuestos en que la pena de prisión es ejecutada en régimen ordinario en toda su extensión no se plantea problema alguno; acreditada la peligrosidad criminal se ejecutará la libertad vigilada, que a su vez actuará como una suerte de libertad condicional aplazada. Incluso en estos casos, podría plantearse el hecho de que la libertad vigilada no se ejecutara cuando quedara acreditado que, aun existiendo riesgo de reincidencia, el reo no ha podido ampararse en un plan individualizado de reeducación y reinserción social, de modo que no puede pretenderse lograr unas determinadas finalidades que debieran haberse perseguido durante la ejecución de la pena de prisión ${ }^{34}$. En los supuestos en que se hubiera cumplido la última parte de la pena en régimen de semilibertad, sólo debería finalmente ejecutarse la libertad vigilada cuando se hubiera producido un retroceso en la reinserción social del sujeto. Tal afirmación se deriva del hecho que para la obtención del tercer grado penitenciario o de la propia libertad condicional la ley ya exige que el interno presente un buen pronóstico de reinserción lo que se contradice con la existencia de un riesgo de reincidencia. No obstante, nada impide que cumplida la última parte de la pena de prisión en régimen de libertad condicional se dé inicio a la ejecución de la libertad vigilada. Es más, el artículo 23 del RD 840/2011 prevé esta opción de forma expresa y, como se ha visto supra, los tribunales también han confirmado tal posibilidad.

Tomada la decisión de activar la ejecución de la libertad vigilada, será éste el momento en que se deberá, como se ha dicho, establecer las concretas obligaciones y prohibiciones que van a imponerse. Para ello, deberán tenerse en cuenta las necesidades que tenga la persona sometida a la medida, y su imposición deberá ser respetuosa, en todo lo posible, con el desarrollo de su vida familiar y laboral, de modo que se facilite la reinserción del sujeto. Lo ideal sería, como indica CID MOLINÉ, que en principio se impusieran únicamente aquellas obligaciones y prohibiciones con una finalidad marcadamente correctiva y dejar aquellas que sólo tienen un contenido de control para los casos en que se pusiere de manifiesto, desde un principio o posteriormente a través de la modificación del contenido de la libertad vigilada, un rechazo de la persona a

\footnotetext{
${ }^{33}$ En este mismo sentido, vid. GARCÍA ALBERO, R., «De las medidas de seguridad», en QUINTERO OLIVARES, G. (Dir.), Comentarios al Código Penal español, cit., p. 693, quien se pregunta si «la nula mención al problema, por parte del legislador, revele, en una suerte de desliz freudiano, la convicción de que ni los delincuentes sexuales ni los terroristas merecen nunca los beneficios del sistema de individualización científica».

${ }^{34}$ En este sentido, vid. CID MOLINÉ, J., «La medida de seguridad de libertad vigilada (artículos 106 CP y concordantes)», en SILVA SÁNCHEZ, J. M. (dir.), El nuevo Código Penal. Comentarios a la reforma, cit., pp. 197-198. s[Ḷp?
} 
colaborar en su proceso de rehabilitación y, finalmente, las de protección a la víctima sólo cuando sean solicitadas por la propia víctima y se planteen como necesarias para evitar una nueva victimización ${ }^{35}$. No obstante, la realidad será otra, pues es difícilmente creíble que lo que se pretenda con la libertad vigilada realmente sea resocializar a aquel que no ha sido rehabilitado en prisión.

Asimismo, en el momento de establecer las concretas obligaciones y prohibiciones a imponer, deberá tenerse en cuenta si, en sentencia condenatoria, junto con la pena de prisión y la libertad vigilada, se impusieron, por vía del artículo $57 \mathrm{CP}$, o vía artículo $578 \mathrm{CP}$ para determinados delitos de terrorismo, alguna de las penas accesorias reguladas en el artículo $48 \mathrm{CP}$. A saber, si en sentencia condenatoria se impone alguna de las penas accesorias establecidas en el artículo 48, coincidentes en contenido y fundamento con algunas de las prohibiciones tendentes a la protección de terceras personas que conforman la libertad vigilada, no será posible su concreción en sede de libertad vigilada, o por el contrario se estaría infringiendo el principio non bis in $i_{\text {íem }}^{36}$. El problema está en determinar cuál de las prohibiciones no debe imponerse, si la acordable en sede de pena accesoria o de libertad vigilada. Personalmente, creo que la solución sólo puede ser una: si se decide imponer alguna de las prohibiciones contenidas en el artículo $48 \mathrm{CP}$ como pena accesoria vía artículo $57 \mathrm{CP}$ deberá decidirse en sentencia condenatoria, de modo que en el momento de determinar el concreto contenido de la libertad vigilada, las primeras ya estarán impuestas. Consecuentemente, en el momento de determinar el contenido de la libertad vigilada deberán tomarse en consideración las penas accesorias impuestas y de ser así no imponerlas como prohibiciones de la medida de seguridad ${ }^{37}$.

Contrariamente a la doctrina, el Tribunal Supremo ha indicado que resulta posible la imposición de una prohibición de alejamiento como pena accesoria y como contenido de la libertad vigilada. En este sentido, vid. las SSTS (sala 2a) 347/2013, de 9 de abril, y 618/2014, de 24 de septiembre. En ellas se defiende que el hecho de que la libertad vigilada se ejecute con posterioridad otorga funcionalidad a las penas accesorias durante la ejecución de la pena de prisión. Ambas sentencias no resuelven, empero, las críticas que se han vertido desde la doctrina sobre la problemática que plantea su ejecución conjunta. Esto es, qué sucede en el momento en que debe activarse la medida de libertad vigilada ${ }^{38}$.

\footnotetext{
35 Cfr. en CID MOLINÉ, J., «La medida de seguridad de libertad vigilada (artículos 106 CP y concordantes)», en SILVA SÁNCHEZ, J. M. (dir.), El nuevo Código Penal. Comentarios a la reforma, cit., p. 199.

36 Contrariamente a la opinión aquí defendida, vid. OTERO GONZÁLEZ, P., La libertad vigilada aplicada a ¿imputables? Presente y futuro, cit., pp. 98-99, quien considera que nunca se producirá una

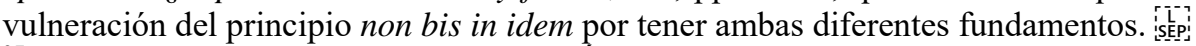

${ }^{37}$ En el mismo sentido, vid. ACALE SÁNCHEZ, M., Medición de la respuesta punitiva y Estado de Derecho, cit., p. 200; GARCÍA ALBERO, R., «De las medidas de seguridad», en QUINTERO OLIVARES, G. (Dir.), Comentarios al Código Penal español, cit., p. 690; SIERRA LóPEZ, M., La medida de libertad vigilada, cit., pp. 110-111; HUERTA TOCILDO, S., «Esa extraña consecuencia del delito: la libertad vigilada», en ÁLVAREZ GARCÍA, F. J/et. al. (coords.), Libro homenaje al profesor Luis Rodríguez Ramos, cit., p. 122; del CARPIO DELGADO, J., «La medida de seguridad de libertad vigilada para delincuentes imputables», cit., pp. 184-186; MARTÍNEZ GARAY, L., «La libertad vigilada: regulación actual, perspectivas de reforma y comparación con la führungsaufsicht del derecho penal alemán», cit., p. 14.

${ }^{38}$ Lo pone de manifestó también MARTÍNEZ GARAY, L., "La libertad vigilada: regulación actual, perspectivas de reforma y comparación con la Fürungsaufsicht del Derecho penal alemán”, cit., pp. 15-16.
} 
Debe reconocerse, no obstante, que es posible la imposición conjunta de dichas prohibiciones como penas y como contenido de la libertad vigilada en los supuestos en que sea necesario complementar - en tiempo o respecto de los sujetos a proteger - la pena accesoria con alguna de las prohibiciones contempladas como parte de la medida de libertad vigilada ${ }^{39}$. En estos supuestos, empero, se generará otro problema: el de las consecuencias de su incumplimiento, pues en el caso de ser configurada como pena accesoria cualquier incumplimiento supondrá el quebrantamiento de la pena y en cambio en sede de libertad vigilada sólo el incumplimiento reiterado o grave supondrá el quebrantamiento de la prohibición. Recientemente, la STS (sala $2^{\text {a }}$ ) 608/2015, de 20 de octubre, consciente de la posible problemática que puede plantear la imposición conjunta de penas accesorias y la libertad vigilada propone para el caso concreto imponer las penas accesorias de aproximación y comunicación con la víctima por el tiempo mínimo legalmente exigido al haberse cometido un delito grave. La sentencia textualmente establece: "teniendo en cuenta que se ha impuesto una medida de libertad vigilada que puede ser concretada en prohibiciones de aproximación y comunicación con la víctima y que se ejecutará finalizado el cumplimiento de la pena, no parece necesario imponer una pena con similar contenido más allá de lo legalmente imprescindible, por lo que procede su reducción al mínimo legal de un año superior a la duración de la pena privativa de libertad, con cumplimiento simultáneo con ésta".

Para evitar los problemas que plantea la libertad vigilada con respecto a la ejecución de la pena de prisión y a su compatibilidad con la imposición de penas accesorias, hubiera tenido más sentido que la ejecución de la libertad vigilada se iniciara junto con la de la pena de prisión y su duración se prolongara, si ello fuera necesario, de acuerdo con la peligrosidad criminal del sujeto, por un tiempo máximo establecido en la ley, al estilo de las penas accesorias ${ }^{40}$. De este modo, en el momento de dictar sentencia aquellas prohibiciones que quisieran imponerse como penas accesorias con carácter facultativo podrían ya serlo como contenido de la libertad vigilada, y únicamente deberían tenerse en cuenta en el momento de determinar el contenido de la libertad vigilada aquellas penas accesorias de imposición preceptiva (artículo $57.2 \mathrm{CP}$ ). Además, aunque durante la primera fase de ejecución de la prisión podría considerarse que no tiene mucho sentido que la libertad vigilada ya se esté ejecutando, ello cobraría sentido en el momento de disfrutar de un permiso penitenciario o en el momento en que se concediera el tercer grado penitenciario y la posterior libertad condicional ${ }^{41}$.

Una vez determinado el contenido de la medida, extinguida la pena de prisión impuesta, se iniciará la ejecución de la misma. Puesto que de una medida de seguridad se trata $\mathrm{y}$, por tanto, sometida al principio de flexibilidad en su ejecución, durante la

\footnotetext{
39 Vid. FEIJOO SÁNCHEZ, B., «La libertad vigilada en el derecho penal de adultos», en DIAZMAROTO VILLAREJO, J. (dir.), Estudios sobre las reformas del Código penal operadas por las LO 5/2010, de 22 de junio, y 3/2011, de 28 de enero, cit., p. 224; TORRES ROSELL, N., «Libertad vigilada y seguimiento continuado de penados: contenido e implicaciones político criminales», cit., p. 10.

${ }^{40}$ En este sentido, vid. GARCÍA ALBERO, R., «De las medidas de seguridad», en QUINTERO OLIVARES, G. (Dir.), Comentarios al Código Penal español, cit., p. 694; SANZ MORÁN, A. J., «La nueva medida de libertad vigilada: reflexión político-criminal», en MUÑOZ CONDE, F., et al. (dirs.), Un Derecho penal comprometido. Libro homenaje al Prof. Dr. Gerardo Landrove Díaz, cit., pp. 1021-1022; MANZANARES SAMANIEGO, J. L., «La libertad vigilada», cit., p. 1510.

${ }^{41}$ Vid. GARCÍA ALBERO, R., «De las medidas de seguridad», en QUINTERO OLIVARES, G. (Dir.), Comentarios al Código Penal español, cit., p. 694; SANZ MORÁN, A. J., «La nueva medida de libertad vigilada: reflexión político-criminal», en MUÑOZ CONDE, F., et al. (dirs.), Un Derecho penal comprometido. Libro homenaje al Prof. Dr. Gerardo Landrove Díaz, cit., pp. 1021-1022. isspe?
} 
ejecución de la medida de libertad vigilada el juez o tribunal podrá, por un lado, acordar la modificación de las obligaciones y prohibiciones impuestas y, por otro, acordar la reducción de la duración de la medida, e incluso poner fin a la misma, en vista del pronóstico positivo de reinserción, cuando considere innecesaria o contraproducente la continuidad de la ejecución de la misma (artículo 106.3 CP). Para ello, deberá seguirse el procedimiento establecido en el artículo $98 \mathrm{CP}$ que establece que el JVP, al menos con carácter anual, valorará los informes emitidos por el servicio de gestión de penas y medidas alternativas y formulará una propuesta de mantenimiento de la medida, modificación de las obligaciones y prohibiciones impuestas, reducción de su duración o cese de la libertad vigilada. La propuesta formulada por el JVP deberá ser elevada al juez o tribunal sentenciador quien resolverá a través de resolución motivada, previa audiencia del sometido a la medida, del Ministerio Fiscal y demás partes, e incluso de las víctimas del delito, aunque no estuvieran personadas, si así lo solicitan. Ello no solventa, sin embargo, el principal misterio que acompaña la ejecución de la libertad vigilada sobre quién debe ser el responsable de velar por el cumplimiento de las obligaciones y prohibiciones impuestas al sujeto. El artículo 98 nos indica, pues, que deberá haber unos facultativos y profesionales que deberán asistir al sometido a la medida, pero nada más se sabe al respecto. El RD 840/2011 tampoco solventa la incógnita, pues directamente elude plantearse la cuestión. Deberá verse qué sucede en la realidad una vez todas estas medidas de libertad vigilada que los tribunales están imponiendo deban ejecutarse. Una solución que propone toda la doctrina es la de crear la figura del agente de libertad vigilada encargado del control de las obligaciones y prohibiciones impuestas y, también, de asistir al propio sujeto ${ }^{42}$.

\section{EL INCUMPLIMIENTO DE LA LIBERTAD VIGILADA}

El régimen de incumplimiento de la medida de libertad vigilada se regula en el art. 106.4 CP. En concreto, se contemplan dos regímenes de actuación en el caso de incumplimiento de las obligaciones - ya sea una o varias - impuestas. En primer lugar, para el supuesto en que el incumplimiento sea leve y, en segundo lugar, para aquellos casos en que el incumplimiento sea grave o reiterado, que revele la voluntad de no someterse a las obligaciones y prohibiciones que hayan sido impuestas. En el primer supuesto, el juez o tribunal sentenciador, de acuerdo con el procedimiento establecido en el artículo $98 \mathrm{CP}$, podrá acordar la modificación de las obligaciones y/o prohibiciones impuestas por otras de las establecidas en el artículo $106.1 \mathrm{CP}$. En el segundo supuesto, el juez deberá, además de modificar las obligaciones o prohibiciones incumplidas si así lo considera, deducir testimonio por la comisión de un delito de

\footnotetext{
${ }^{42}$ Vid., entre otros, GUDÍN RODRÍGUEZ-MAGARIÑOS, F., La nueva medida de seguridad postdelictual de libertad vigilada: especial referencia a los sistemas de control telemáticos, cit., pp. 263271; SIERRA LÓPEZ, M., La medida de libertad vigilada, cit., pp. 105-106; VÁZQUEZ GONZÁLEZ, C., "Algunas cuestiones penales y criminológicas sobre la nueva medida de libertad vigilada", en ÁLVAREZ GARCÍA, F. J / et. al. (Coords.), Libro homenaje al profesor Luis Rodríguez Ramos, cit., pp. 263-264; BOLDOVA PASAMAR, M. A., "Consideraciones político-criminales sobre la introducción de la libertad vigilada", cit., p. 313; ACALE SÁNCHEZ, M., "Libertad vigilada", en ÁLVAREZ GARCÍA, F. J. / GONZÁlEZ CUSSAC, J. L. (Dirs.), Comentarios a la Reforma Penal de 2010, p. 152; MANZANARES SAMANIEGO, J. L., "La libertad vigilada", cit., p. 1513; ARMAZA ARMAZA, E. J., El tratamiento penal del delincuente imputable peligroso, cit., p. 200; MAGRO SERVET, V., "La figura del agente de libertad vigilada en la reforma del Código Penal", en Diario La Ley, n 7074, 2008, passim; MARTÍNEZ GARAY, L., «La libertad vigilada: regulación actual, perspectivas de reforma y comparación con la führungsaufsicht del derecho penal alemán», cit., pp. 22-24.
} 
quebrantamiento de condena regulado en el artículo 468.2 CP castigado con una pena de prisión de 6 meses a 1 año ${ }^{43}$. El legislador, al igual que al configurar el régimen de aplicación de la libertad vigilada para sujetos imputables, ha optado por configurar un régimen de incumplimiento ad hoc —cfr. artículo $100 \mathrm{CP}$ - para la libertad vigilada.

Finalmente, hay un aspecto relacionado con el incumplimiento de la libertad vigilada que el legislador no ha regulado y resulta importante. A saber, qué sucede con la ejecución de la medida de libertad vigilada cuando ésta es quebrantada: ¿Continúa inalterada, su ejecución es suspendida o la medida se extingue? Al respecto, a pesar de la disparidad de opiniones ${ }^{44}$, parece lógico que en aquellos casos en que el incumplimiento de la medida de libertad vigilada implique la comisión de un delito de quebrantamiento, su ejecución quedará inalterada por más que su contenido pueda verse modificado. De hecho, según el propio artículo $106.4 \mathrm{CP}$, en los casos de incumplimiento grave o reiterado el juez debe deducir testimonio por un presunto delito del artículo $468 \mathrm{CP}$, además de poder modificar las obligaciones y prohibiciones impuestas. Luego, si en los casos en que debe deducirse testimonio por la comisión de un delito de quebrantamiento es posible modificar las obligaciones y prohibiciones impuestas, no tiene sentido que inmediatamente se suspenda la ejecución de la medida o que directamente se extinga la misma.

\section{CONCLUSIONES}

Analizado el instituto de la medida de seguridad de libertad vigilada, debe llegarse a la conclusión de que la misma no está pensada para cumplir con fines de prevención especial positiva sino de incapacitación general, pues así se desprende tanto de la misma Exposición de Motivos de la LO 5/2010 y de la del Proyecto de reforma de 2009 como del posible contenido de la libertad vigilada. Respecto al concreto contenido, en abstracto, sólo hay dos concretas obligaciones, cuya obligatoriedad en su ejecución resulta dudosa, que tienen un carácter nítidamente rehabilitador; el resto o pretenden tener controlado al sujeto o tienden a proteger a terceras personas, pero no a reducir el riesgo de reincidencia por un tiempo más allá del de la duración de la medida. De hecho, lo que se dice pretender con la introducción de la libertad vigilada podría ya conseguirse con una modificación del régimen de ejecución de la pena de prisión, de modo que la última fase de ésta se ejecutara, en todo caso, en régimen de libertad condicional.

Sin embargo, en caso de considerarse necesario el mantenimiento de la medida de seguridad de libertad vigilada, el legislador debería entonces realizar una verdadera

\footnotetext{
${ }^{43}$ Vid. del CARPIO DELGADO, J., «La medida de seguridad de libertad vigilada para delincuentes imputables», cit., p. 190, quien, incorrectamente, considera que en el caso de incumplimiento por parte de un inimputable o semiimputable debería optarse por la aplicación del apartado primero del artículo 468 CP.

${ }^{44}$ Vid. SIERRA LÓPEZ, M., La medida de libertad vigilada, cit., p. 154, quien considera que siempre que sea posible deberá continuar ejecutándose. Contrariamente, vid. FEIJOO SÁNCHEZ, B., «La libertad vigilada en el derecho penal de adultos», en DIAZ-MAROTO VILLAREJO, J. (dir.), Estudios sobre las reformas del Código penal operadas por las LO 5/2010, de 22 de junio, y 3/2011, de 28 de enero, cit., p. 228 , quien considera que durante la ejecución de la pena de prisión la ejecución de la libertad vigilada quedaría suspendida.
} 
modificación del sistema de sanciones penales orientándolo hacia un modelo dualista en toda regla y no, como ahora, introduciendo la posibilidad de imponer medidas de seguridad a imputables a la vez que manteniendo el actual régimen de penas con la previsión de la agravante de reincidencia, la previsión de penas accesorias, etc.

Igualmente, en tanto que medida de seguridad, la libertad vigilada debería imponerse, en todo caso, con carácter discrecional. No puede entenderse como el legislador prevé supuestos en que se presume un riesgo de reincidencia, por mucho que finalmente pueda acordarse que la libertad vigilada no se ejecute. Más cuando por la propia naturaleza de la libertad vigilada en principio el delito cometido no es más que la constatación de la peligrosidad criminal del sujeto pero no debería servir como base para justificar su imposición. Además, se ha visto como este criterio de la gravedad del delito ha planteado en la práctica judicial cierto caos, hasta el punto que algunos tribunales han tomado en consideración para determinar la imposición o no de la libertad vigilada la pena en concreto. De la misma forma, debería atenderse al riesgo de comisión de nuevos delitos para determinar la duración máxima de la medida en cada caso concreto y no la gravedad del delito cometido. El legislador de 2015 tenía la oportunidad de solventar este disparate, pero en su lugar ha complicado aún más su régimen de imposición, de modo que acrecienta el desconcierto previo al prever un sistema de imposición potestativo para los nuevos supuestos en que es posible la imposición de la libertad vigilada sin a su vez modificar el previsto para los delincuentes sexuales y terroristas.

La libertad vigilada aplicable a sujetos imputables se ejecuta en todo caso una vez cumplida la pena de prisión, momento en el que, a pesar de que la jurisprudencia menor no parezca tenerlo muy claro, debe concretarse su contenido. El hecho de que la ejecución de la libertad vigilada se inicie con el definitivo licenciamiento del reo, empero, plantea problemas en relación con el disfrute de beneficios penitenciarios y con la obtención del tercer grado penitenciario y la libertad condicional. En estos casos, a pesar de lo defendido por el Tribunal Supremo, sólo debería finalmente ejecutarse la libertad vigilada cuando, habiéndose obtenido el tercer grado o la libertad condicional, se hubiera producido un retroceso en la reinserción social del sujeto.

La ejecución de la libertad vigilada en los supuestos de delitos graves plantea asimismo otro problema importante, dado que algunas de las obligaciones y prohibiciones contenidas en la medida coinciden con el contenido de determinadas penas accesorias de posible imposición tanto a los sujetos que cometan un delito contra la libertad e indemnidad sexual como de terrorismo. A pesar de que el Tribunal Supremo admita tal posibilidad al considerar que la pena accesoria cumple una finalidad concreta durante la ejecución de la pena de prisión, no se resuelve el verdadero problema: el que se plantea con el inicio de la ejecución de la libertad vigilada. En estos casos, en el momento de concretar las obligaciones y prohibiciones a imponer, debería tenerse en cuenta si, en sentencia condenatoria, junto con la pena de prisión y la libertad vigilada, se impusieron, por vía del art. $57 \mathrm{CP}$, alguna de las penas accesorias establecidas en el art. $48 \mathrm{CP}$.

Ante el desajuste legislativo del que se ha pretendido dar cuenta en este trabajo resultaría adecuado aprovechar la próxima reforma penal para plantear una solución a los distintos problemas que plantea su regulación. La misma podría pasar bien por la derogación de la libertad vigilada, bien por la creación de una institución en armonía 
con el resto del sistema de sanciones penales y dotando a la misma de recursos. Hasta que ello no ocurra deberemos esperar que sean los propios tribunales quienes resuelven los distintos problemas planteados: los que se derivan de una aplicación incorrecta de la ley por parte de la jurisprudencia menor y, sobre todo, los que tienen como razón los claroscuros de la propia regulación de la medida.

\section{BIBLIOGRAFÍA}

ACALE SÁNCHEZ, M., "Medidas de seguridad. En especial, la custodia de seguridad", en ÁLVAREZ GARCÍA, F. J. (Dir.), Estudio crítico sobre el anteproyecto de reforma penal de 2012, Ed. Tirant lo Blanch, Valencia, 2013.

ACALE SÁNCHEZ, M., «Libertad vigilada», en ÁLVAREZ GARCÍA, F. J. /GONZÁlEZ CUSSAC, J. L. (Dirs.), Comentarios a la Reforma Penal de 2010, Ed. Tirant lo Blanch, Valencia, 2010.

ACALE SÁNCHEZ, M., «Libertad vigilada», en ÁLVAREZ GARCÍA, F. J. /GONZÁLEZ CUSSAC, J. L. (DIRS.), Consideraciones a propósito del Proyecto de Ley de 2009 de modificación del Código Penal, Ed. Tirant lo Blanch, Valencia, 2010.

ACALE SÁNCHEZ, M., Medición de la respuesta punitiva y Estado de Derecho, Ed. Aranzadi, Cizur Menor, 2011.

ARMAZA ARMAZA, E. J., El tratamiento penal del delincuente imputable peligroso, Ed. Comares, Granada, 2013.

BENÍTEZ ORTÚZAR, I., «La nueva «medida de seguridad» de «libertad vigilada» aplicable al sujeto imputable tras el cumplimiento de la pena privativa de libertad. La admisión de los postulados del «derecho penal del enemigo» por la LO 5/2010», en Cuadernos de Política Criminal, núm. 103, 2011.

BOLDOVA PASAMAR, M. A., «Consideraciones político-criminales sobre la introducción de la libertad vigilada», ReCrim, núm 2, 2009.

CEREZO MIR, J., "Reflexiones críticas sobre algunas manifestaciones de la moderna tendencia a incrementar el rigor en la exigencia de responsabilidad criminal", en Revista penal, núm. 22, 2008.

CID MOLINÉ, J., «La medida de seguridad de libertad vigilada (artículos $106 \mathrm{CP}$ y concordantes)», en SILVA SÁNCHEZ, J. M. (dir.), El nuevo Código Penal. Comentarios a la reforma, Ed. La Ley, Madrid, 2012.

CÓRDOBA RODA, J., «Prescripción del delito, libertad vigilada y comiso», en Revista Jurídica de Catalunya, vol. 110, núm. 4, 2011.

DE MARCOS MADRUGA, F., «De las medidas de seguridad», en Gómez Tomillo, M. (dir.), Comentarios al Código Penal, Ed. Lex nova, Valladolid, 2011.

DEL CARPIO DELGADO, J., «La medida de seguridad de libertad vigilada para delincuentes imputables», en Revista de Derecho Penal y Proceso Penal, núm. 27, 2012 .

FEIJOO SÁNCHEZ, B., «La libertad vigilada en el derecho penal de adultos», en DIAZ-MAROTO VILLAREJO, J. (DIR.), Estudios sobre las reformas del Código 
penal operadas por las LO 5/2010, de 22 de junio, y 3/2011, de 28 de enero, Ed. Civitas, Madrid, 2011.

GARCÍA ALBERO, R., «De las medidas de seguridad», en QuINTERO Olivares, G. (Dir.), Comentarios al Código Penal español, Ed. Aranzadi, 2011.

GARCÍA RIVAS, N., «La libertad vigilada y el derecho penal», en DEMETRIO CRESPO, E. (dir.), Neurociencias y derecho penal. Nuevas perspectivas en el ámbito de la culpabilidad y tratamiento jurídico penal de la peligrosidad, Ed. Edisofer, Madrid, 2013.

GÓMEZ MARTÍN, V., «La reforma de la parte general del código penal (Lo 5/2010, de 22 de junio): ¿avance o retroceso?», en Revista Catalana de Seguretat Pública, núm. 27, 2011.

GUDÍN RODRÍGUEZ-MAGARIÑOS, G., La nueva medida de seguridad postdelictual de libertad vigilada: especial referencia a los sistemas de control telemáticos, Ed. Tirant lo Blanch, Valencia, 2012.

HUERTA TOCILDO, S., «Esa extraña consecuencia del delito: la libertad vigilada», en ÁLVAREZ GARCÍA, F. J/et. al. (coords.), Libro homenaje al profesor Luis Rodríguez Ramos, Ed. Tirant lo Blanch, Valencia, 2012.

JIMÉNEZ MARTÍNEZ, C., «La libertad vigilada en el CP de 2010. Especial mención a la libertad vigilada para imputables peligrosos»», en Revista de Derecho Penal y Criminología, $3^{\mathrm{a}}$ Época, núm. 7, 2012. istęp:

LEAL MEDINA, J., Un estudio de las actuales medidas de seguridad y los interrogantes que plantean en la moderna dogmática del Derecho penal, Ed. Aranzadi, Cizur Menor, 2008.

MAGRO SERVET, V., «La figura del agente de libertad vigilada en la reforma del código penal», en Diario La Ley, núm. 7074, 2008.

MANZANARES SAMANIEGO, J. L., «La libertad vigilada», en Diario La Ley, núm. 7386, 2010.

MARTÍNEZ GARAY, L., "La libertad vigilada: regulación actual, perspectivas de reforma y comparación con la Fürungsaufsicht del Derecho penal alemán”, en Revista General de Derecho Penal, núm. 22, 2014.

MAZA MARTÍN, J. M., "La necesaria reforma del Código Penal en materia de medidas de seguridad", en ECHAVARRI GARcíA, M., Las penas y medidas de seguridad, Ed. Consejo General del Poder Judicial. Centro de Documentación Judicial, Madrid, 2007.

MUÑOZ CONDE, F., "Monismo y dualismo en el Derecho penal español”, Estudios penales y criminológicos, núm. 6, 1981-1982.

OTERO GONZÁLEZ, P., La libertad vigilada aplicada a ¿imputables? Presente y futuro, Ed. Dykinson, 2015.

PÉREZ BELLO, B., «Ejecución de penas y medidas de seguridad, en especial la libertad vigilada», en Revista Jurídica de Catalunya, núm. 4, 2011.

ROCA POVEDA, M., «La libertad vigilada. Notas desde una visión penitenciaria», en La Ley Penal, núm. 96-97, 2012.

ROBLES PLANAS, R., "Sexual Predators. Estrategias y límites del derecho penal de la peligrodidad", Indret, 4/2007. 
SALAT PAISAL, M., «La regulación de la libertad vigilada en la proyectada reforma del Código Penal», en Revista de Derecho y Proceso Penal, núm. 34, 2014.

SALAT PAISAL, M., La respuesta jurídico-penal a los delincuentes imputables peligrosos: especial referencia a la libertad vigilada, Ed. Aranzadi, Cizur Menor, 2015.

SANZ MORÁN, Á. J., "Medidas de Seguridad", en ÁLVAREZ GARCÍA, F. J. (Dir.), Estudio crítico sobre el anteproyecto de reforma penal de 2012, Ed. Tirant lo Blanch, Valencia, 2013.

SANZ MORÁN, A. J., «La nueva medida de libertad vigilada: reflexión políticocriminal», en MuÑoz CONDE, F., et al. (dirs.), Un Derecho penal comprometido. Libro homenaje al Prof. Dr. Gerardo Landrove Díaz, Ed. Tirant lo Blanch, Valencia, 2011.

SANZ MORÁN, A. J., «Libertad vigilada y quebrantamiento de condena: artículos 106 y 468 CP», en ÁlVAREZ GARCÍA, F. J. /GONZÁLEZ CUSSAC, J. L. (dirs.), Consideraciones a propósito del Proyecto de Ley de 2009 de modificación del Código Penal, Ed. Tirant lo Blanch, Valencia, 2010.

SANZ MORÁN, A. J., Las medidas de corrección y de seguridad en el derecho penal, Ed. Lex Nova, 2003.

SIERRA LÓPEZ, M., La medida de libertad vigilada, Ed. Tirant lo Blanch, Valencia, 2013.

SILVA SÁNCHEZ, J. Ma , El nuevo Código Penal: cinco cuestiones fundamentales, Ed. Bosch, Madrid, 1997.

TAMARIT SUMALLA, J. M., «Delitos relativos a la pornografía infantil y otras medidas relacionadas con la delincuencia sexual, artículos 189 y 192 CP», en QUINTERO OLIVARES, G. (dir.), La reforma penal de 2010: análisis y comentarios, Ed. Aranzadi, Cizur Menor, 2010.

TORRES ROSELL, N., «Libertad vigilada y seguimiento continuado de penados: contenido e implicaciones político criminales», en Revista Electrónica de Ciencia Penal y Criminología, 14-06, 2012.

VÁZQUEZ GONZÁLEZ, C., «Algunas cuestiones penales y criminológicas sobre la nueva medida de libertad vigilada», en ÁLVAREZ GARCÍA, F. J./et al. (coord.), Libro homenaje al profesor Luis Rodríguez Ramos, Ed. Tirant lo Blanch, Valencia, 2012.

ZUGALDÍA ESPINAR, J. M., "Medidas de Seguridad", en ÁLVAREZ GARCÍA, F. J. (Dir.), Estudio crítico sobre el anteproyecto de reforma penal de 2012, Ed. Tirant lo Blanch, Valencia, 2013.

\section{JURISPRUDENCIA CITADA}

\section{Tribunal Supremo}

ATS (sala $2^{\text {a }}$ ) 1270/2014, de 10 de julio.

STS (sala $2^{\mathrm{a}}$ ) 608/2015, de 20 de octubre.

STS (sala $2^{\mathrm{a}}$ ) 76/2015, de 23 de noviembre.

STS (sala $2^{\mathrm{a}}$ ) 768/2014, de 11 de noviembre.

STS (sala $2^{\text {a }) ~ 347 / 2013, ~ d e ~} 9$ de abril.

STS (sala 2a) 618/2014, de 24 de septiembre.

STS (sala 2a) 768/2014, de 11 de noviembre. 


\section{Audiencias Provinciales}

SAP de Albacete (secc. $2^{\mathrm{a}}$ ) 281/2015, de 16 de julio. SAP de Ávila (secc. 1 ${ }^{\text {a }}$ ) 164/2015, de 27 de noviembre. SAP de Badajoz (secc. $1^{\text {a }}$ ) 33/2015, de 22 de septiembre. SAP de Barcelona (secc. 2) 686/2015, de 9 de septiembre. SAP de Barcelona (secc. 20a) 509/2015, de 1 de julio. SAP de Barcelona (secc. 22) 372/2015, de 8 de julio. SAP de Barcelona (secc. $3^{\text {a }}$ ) 628/2015, de 13 de octubre. SAP de Barcelona (secc. $8^{a}$ ) 651/2015, 17 de septiembre. SAP de Barcelona (secc. 9a) 304/2015, de 1 de abril. SAP de Barcelona (secc. 6 ${ }^{\mathrm{a}}$ ) 167/2014, de 24 de febrero. SAP de Barcelona 47/2015, de 27 de noviembre. SAP de Cáceres (secc. 2a) 349/2014, de 5 de septiembre.

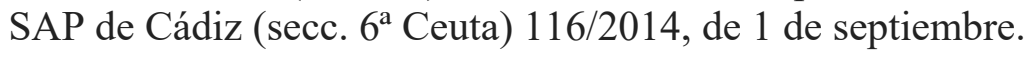
SAP de Córdoba (secc. $3^{\text {a }}$ ) 365/2015, de 23 de julio. SAP de Granada (secc. 2a) 477/2015, de 15 de julio. SAP de Lleida (secc. $1^{\text {a }}$ ) 72/2014, de 10 de marzo. SAP de Lugo (secc. $2^{\mathrm{a}}$ ) 133/2014, de 16 de julio. SAP de Madrid (secc. 16 ) $^{\text {707/2015, de }} 20$ de octubre. SAP de Madrid (secc. 16a) 740/2015, de 8 de julio. SAP de Madrid (secc. 5a) 79/2015, de 7 de octubre. SAP de Madrid (secc. 6a) 618/2015, de 11 de septiembre. SAP de Madrid (secc. $7^{\text {a }}$ ) 840/2015, de 23 de octubre. SAP de Mérida (secc. $3^{\text {a }}$ ) 194/2015, de 9 de julio. SAP de Murcia (secc. 3 $3^{\text {a }}$ 397/2015, de 22 de septiembre. SAP de Oviedo (secc. $3^{\text {a }}$ ) 511/2015, de 14 de diciembre. SAP de Palma de Mallorca (secc. $2^{\text {a }}$ ), de 10 de julio. SAP de Valencia (secc. 2a) 984/2015, de 15 de diciembre. SAP de Valencia (secc. 4a 476/2015, de 8 de julio. SAP de Valencia (secc. $5^{\text {a }}$ ) 642/2015, de 20 de septiembre. SAP de Valladolid (secc. 2a) 305/2015, de 23 de noviembre. SAP de Valladolid (secc. $2^{\text {a }}$ ) 305/2015, de 23 de noviembre. SAP de Valladolid (secc. 4a) 294/2014, de 24 de septiembre. SAP de Zamora (secc. $1^{\text {a }}$ ) 27/2015, de 8 de octubre. SAP de Zaragoza (secc. 6a) 306/2015, de 18 de noviembre. SAP de Oviedo (secc. $3^{\text {a }}$ ) 511/2015, de 14 de diciembre. 